\title{
Pneumocystis Carinii Pneumonitis A Review
}

\author{
J.B. RobBins \\ Departments of Pediatrics and Microbiology, University of Florida, Gainesville, Fla. 32601, USA
}

\begin{abstract}
Introduction
The purpose of this essay is to organize the available information about Pneumocystis carinii pneumonitis and to relate the host factors and the pathophysiology with the clinical disease. Since a successful chemotherapeutic approach has been reported by several workers, and since the incidence of this disease seems to be increasing in a select group of patients, it is important that the early ante mortem diagnosis of this disease be established. The emphasis in this essay, therefore, will be to relate the unique characteristics of the pathogen to the pathophysiological state characteristic of the pneumonitis induced by Pneumocystis carinii. It is hoped that a logical analysis of the data with illustrative case material will permit a distinct clinical picture to emerge and to pose some new question about the pathogen and the unique host-parasite interaction which may be subject to experimentation.

Several reviews have been extremely useful in the preparation of this manuscript and should be referred to for a historical prospective as well as a more comprehensive review of this literature [1-6].

Pneumocystis carinii pneumonitis is a disease induced by an ubiquitous organism of low virulence and narrow tissue specificity in a susceptible host. In most instances, it is a latent infection which occurs in humans and animals at all stages of development. The distinction, drawn by several workers, between the infantile and adult form of the disease may be due to the narrow age range of patients observed by individual authors. One aim of this review, therefore, will be to show that the same host factors which permit infection with Pneumocystis carinii are operative in humans and animals of all ages. For instance, contagion, formerly thought to be exclusively a feature of the infantile form of the disease has been shown to be an important factor in the transmission of the disease to adults.
\end{abstract}

In many instances, the desperate clinical condition of the affected individuals seems to have precluded those clinical studies necessary to understand the distinctive and altered physiology of Pneumocystis carinii pneumonitis. However, there are some reports, as well as unreported data available to the author, which correlate the pathological findings with the clinical picture of this disease. The review will try to emphasize these pathophysiologic features in order to present those diagnostic hints which the physicians may readily test. Recognition of these unusual clinical features should aid early diagnosis of Pneumocystis carinii pneumonitis.

Of particular interest is the possibility that accurate analysis of the incidence of immunoglobulin deficiency syndromes in the general population may be influenced by Pneumocystis carinii infections. Statistics that project the incidence of immunoglobulin deficiency syndromes in the general population may disregard many cases of immunoglobulin deficiency disease, especially hypogammaglobulinemic states of the congenital variety, which were previously classified as examples of the newborn human's unusual susceptibility to Pneumocystis disease. The wide-spread use of more precise diagnostic techniques for the immunoglobulin deficiency syndromes, as well as the increased attention of pathologists to this diagnosis, should reveal that many children with hypogammaglobulinemic states are afflicted with Pneumocystis carinii infection within the first year of life. The difficulties in substantiating a diagnosis of hypogammaglobulinemia during this age period, however, must be appreciated.

\section{Case 1, figures $1 A-D$}

E.T.F., an 8-year-old girl, was admitted to the University of Florida Teaching Hospital for the second 
Folds, Liso Age:llyears Diagnosis:Acquired Hypogammaglobulinemia

\begin{tabular}{|c|c|}
\hline F IMUUNOCLCCIROPHORISIS & $\begin{array}{l}\text { CELLULOSE ACETATE ELECIROPHORESIS } \\
\qquad \begin{aligned} \text { Total Protein }=6.29 \mathrm{gm}, x \\
\text { Albumin }: 3.77 \\
\alpha_{1}: 0.33 \\
\mathrm{a}_{2}: 0.84 \\
\beta=1.01 \\
\gamma: 0.33\end{aligned}\end{array}$ \\
\hline $\begin{array}{l}\text { SERUM IMMUNOGLOBULIN LEVELS } \\
\qquad \begin{aligned} \text { IgA }=0 \mathrm{mg} . \mathrm{s} \\
\operatorname{IgM}=0 \mathrm{mg} . \mathrm{s} \\
\operatorname{lgc}=360 \mathrm{mg} . \mathrm{s}\end{aligned}\end{array}$ & \\
\hline $\begin{array}{l}\text { CLINICAL SYMPTOMS: } \\
\text { Frequent bacterial pneumonia } \\
\text { Chronic ofitis media with hearing deficit } \\
\text { Pneumocystis carinil pneumonitis }\end{array}$ & $\begin{array}{l}\text { Isohemagglutinins: Blood type A } \\
\text { Anti-B-0 } \\
\text { Anti-diphtheria toxin: } 0.0015 \quad 1.11 .1 \mathrm{ml} \text {. } \\
\text { Bone marrow plasma cells: } 011000\end{array}$ \\
\hline
\end{tabular}
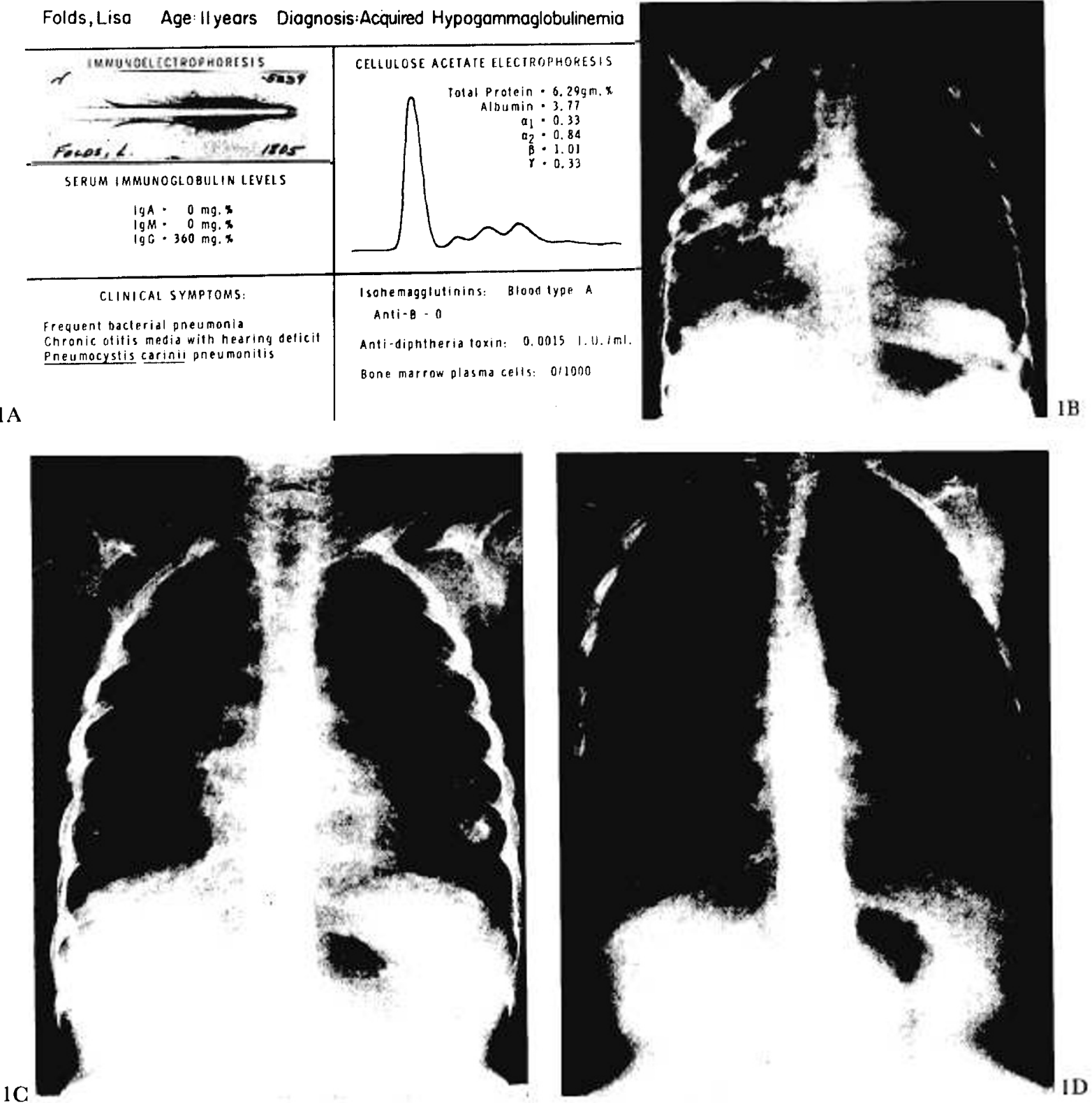

Fig. 1. A. Laboratory data. B. X-ray, acute phase of disease. $C$. One month post pentamidine therapy. $D$. Threc years post therapy.

time on July 31, 1964, with the chief complaint of fever and dry cough, associated with increasing respiratory difficulty. The patient had had recurrent respiratory infections during her entire life. Numerous bouts of otitis media had necessitated multiple myringotomies. Severe attacks of bronchitis, with several episodes of pneumonia, were successfully treated with antibiotics.

The vital capacity as determined with a Collins vitalometer was 0.7 liter (normal 2.0 liter). X-ray study revealed minimal pulmonary scarring without evidence of acute disease. An appropriate work-up was consistent with a diagnosis of hypogammaglobulinemia.

Treatment was started with intramuscular injections of pooled commercial Cohn fraction II, $0.6 \mathrm{ml}$ per kilogram of body weight every month. She remained in relatively good health until 4 weeks before admission, when a dry cough developed. Two weeks later she became slightly febrile, with lethargy and 

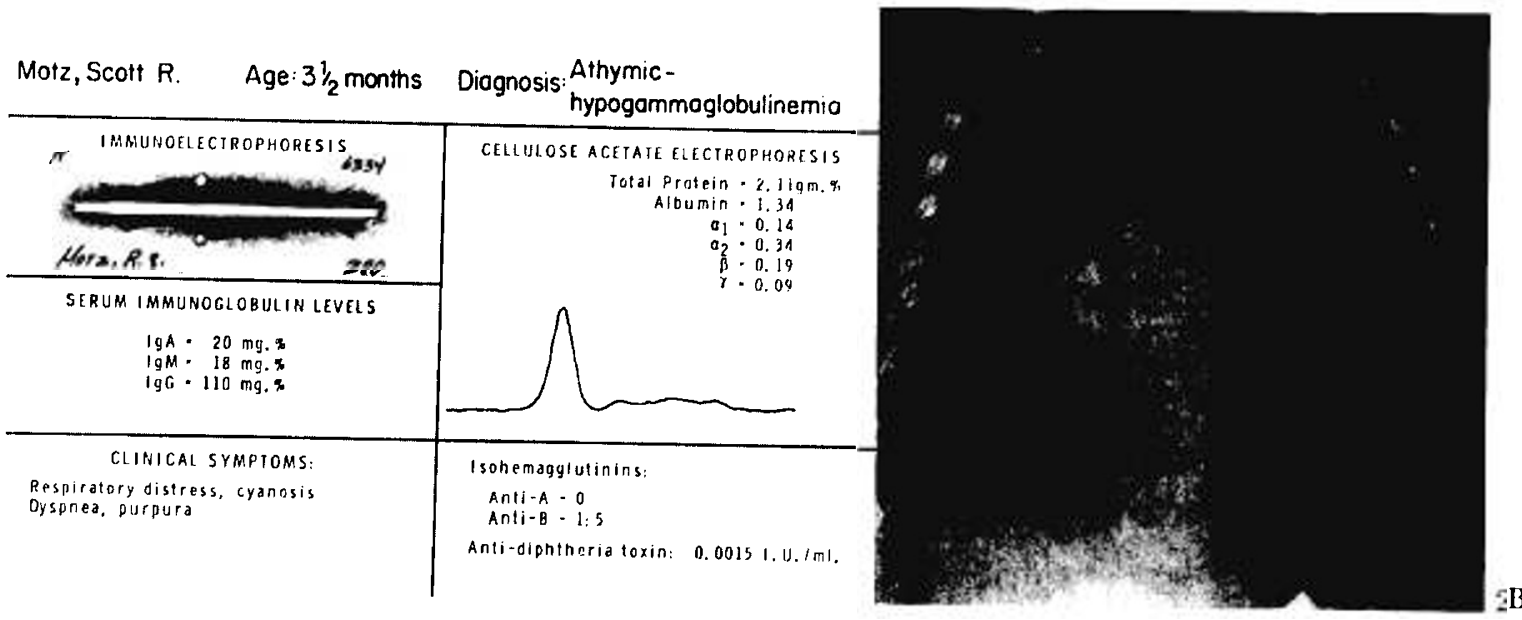

decreased appetite. The cough remained nonproductive, and there was no improvement in the clinical condition despite tetracycline therapy. X-ray study of the chest on the day of admission revealed diffuse bilateral infiltrates most prominent at the hilar regions.

Physical examination showed a thin, chronically ill girl in no acute distress. Diminished chest expansion, decreased breath sounds and hyporesonant percussion were noted in the lung fields bilaterally. No adventitious sounds were heard, and clubbing was not present.

The temperature was $101.5^{\circ} \mathrm{F}\left(38.6^{\circ} \mathrm{C}\right)$, the pulse 130 , and the respirations 44 . The blood pressure was $95 / 75$.

The white-cell count was 21,000 , with $87 \%$ neutrophils, $6^{\circ}$ band forms, $3^{\circ}$ o cosinophils, $2^{\circ}$ lymphocytes and $2 \%$ monocytes. The hematocrit was $37 \%$; the red cells and platelets had normal morphology. Urinalysis was negative. Multiple cultures revealed no pathogens. Fungi and $P$. rarinii, sought with specific stains, were not demonstrated. High doses of penicillin, kanamycin and oxacillin were administered, but the patient's condition deteriorated over the next 7 days. Breathing became labored and shallow; the respirations rose to 80. Attempts at removal from a moist oxygen-enriched environment provoked severe cyanosis. Thoracotomy under light general anesthesia was performed to obtain a lung biopsy. A relatively avascular, yellowish, stiff pulmonary parenchyma was noted. The pleural surfaces were grossly normal. The biopsy specimen obtained was characteristic in appearance for Pneumocystis carinii pncumonitis. Immediately after the diagnosis was established by means of the frozen section, hydroxystilbamidine, $4 \mathrm{mg}$ per kilogram of body weight, was injected intravenously each day. Threc days later this was replaced by therapy with pentamidine isothionate, $4 \mathrm{mg}$ per kilogram intramuscularly, which was then given for 14 days. During this period, all other chemotherapy was discontinued.
After one week of therapy definite clinical improvement was observed. Decreased respiratory embarrassment, as indicated by gradual diminution in cyanosis, less dependency upon oxygen and a return of appetite, was noticed during the lst week of therapy. Roentgenographic evidence of improvement was detectable 3 weeks after treatment was started. Bone-marrow aspirations before therapy and on the 7 th, 11 th, and 14 th days of therapy showed the gradual development of erythroid hyperplasia (myeloid-erythroid ratio of $1: 2$ ), with marked megaloblastic changes. Occasional hypersegmented neutrophils and macroovalocytes were seen in the peripheral blood.

Clinical improvement continued, and the patient was discharged on the 48th hospital day with routine therapy of pooled gamma globulin at monthly intervals. Bone-marrow aspiration done the day before discharge was within normal limits. One month later she exhibited little respiratory embarrassment, with a weight gain of $2 \mathrm{~kg}$, and was maintaining a full program of activity without difficulty. The vital capacity was 0.8 liter (normal, 2.0 liter) at that time, not significantly different from that obtained at a clinic visit before this episode ( 0.7 liter $)$.

Continued sino-pulmonary infections have persisted despite antibiotic therapy. Her vital capacity has risen to 1.5 liters. Currently, she enjoys a full range of activity.

\section{Ciase 2, figures $2 A$ and $B$}

This four month old male was brought to the hospital with a chief complaint of increasing respiratory distress, cyanosis, fever, and weight loss. Following a normal gestation and normal delivery, this infant developed frequent severe upper respiratory infections until the age of threc and a half months. These were successfully 


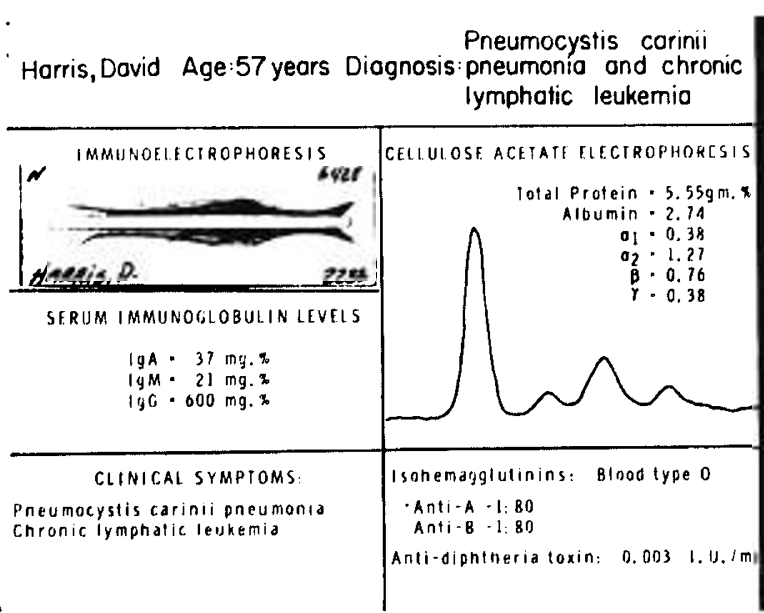

treated with antibiotics. At age three and a half months, he was admitted to a local hospital where he was treated with blood transfusions, antibiotics, and parenteral gamma globulin for severe upper respiratory infection. With increasing cyanosis and respiratory distress, he was transferred to the University of Florida Teaching Hospital.

Upon admission, he was noted to be a severely ill child with cyanosis and dyspnea. Scattered rales were heard throughout both lung fields. There was no palpable lymph node tissue and the liver and spleen were not enlarged. White blood count was 12,000 with 700 lymphocytes per $\mathrm{mm}^{3}$. Nose and throat and blood cultures were essentially non informative. Blood transfusions, antibiotics, and oxygen were offered but the child expired 24 hours after admission.

Autopsy verified the diagnosis of thymic aplasia with hypogammaglobulinemia. No thymus was detected after careful sectioning of the mediastinal contents. Diffuse Pneumocystis carinii pneumonitis was present. There were no inclusion bodies seen.

\section{Case 3, figures $3 A$ and $B$}

This 57-year-old man was admitted on November 12, 1966. In 1963, a diagnosis of chronic lymphatic leukemia was established, and in 1964 and 1965, the patient had radiation to the mediastinum because of the involved nodes having caused some venous compression. A short course of cytoxan therapy was administered and small doses of Chlorambucil were given in 1965 . In February of 1966, the patient had chest pain, which was attributed to arteriosclerotic heart disease. In March of 1966, he was admitted to the hospital for bronchopneumonia and he responded to massive doses of penicillin, Chloromycetin, Keflin and streptomycin, along with very large doses of gamma globulin. No

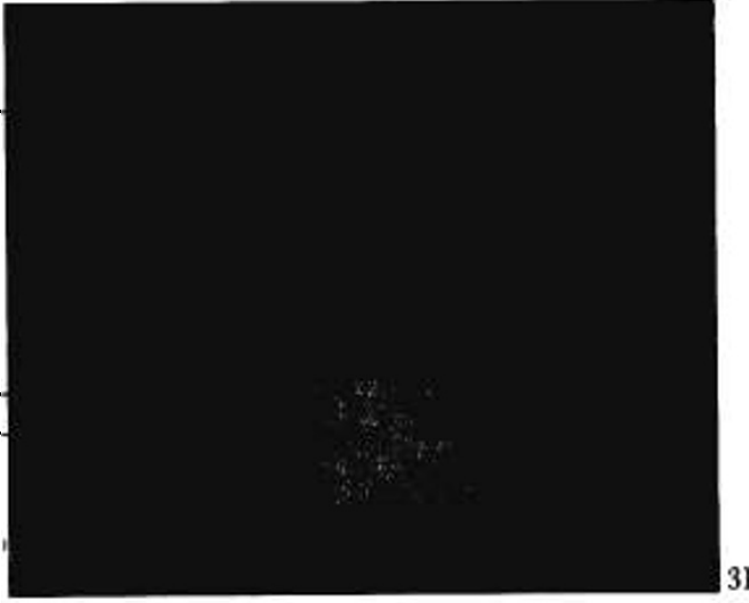

specific organism was cultured at that time. Following discharge, he was placed on very large doses of Prednisone, because of large leukemic lymph nodes and a marked rise in his white count. He responded to this treatment and subsequently was placed on a maintenance dose of Prednisone of $15 \mathrm{mg}$ per day. During October of 1966, he was given two 2-week courses of Chlorambucil. Complaints of cough, weakness and shortness of breath and also a congestive feeling in the chest were related. About ten days prior to admission, fever was noted, and the symptoms mentioned above seemed to be worsening. One week before admission, penicillin therapy was given in conjunction with large doses of gamma globulin in the assumption that once again this was a pulmonary infection, but this treatment was of no value and his chest symptoms increased.

Physical examination on admission revealed his temperature was $101^{\circ} \mathrm{F}$. He was slightly pale, acutely and chronically ill. There were large, nontender, rubbery nodes in the anterior and posterior cervical region as well as in both axilla. The heart was normal, except for a mild tachycardia. A few rales were heard in the right lower lobe. The spleen was palpated three inches and the liver was one inch down below the costal margin. Chest $x$-ray revealed an interstitial infiltrate, especially in the right lung.

On admission, the hemoglobin was 11.1 and the white count 200,000 . The urine was negative. The uric acid was 6.6. Blood and sputum cultures as well as fungal skin tests, gastric aspirates for the culturing of tuberculosis and fungi were all negative.

Antibiotic therapy was begun. Penicillin in high doses was initially given, followed by Keflin, along with streptomycin. These proved to be of no value and the fever spiked to 103 during the first two weeks in the hospital. Chest $\mathrm{x}$-ray became progressively worse, showing very extensive interstitial pulmonary infiltra- 


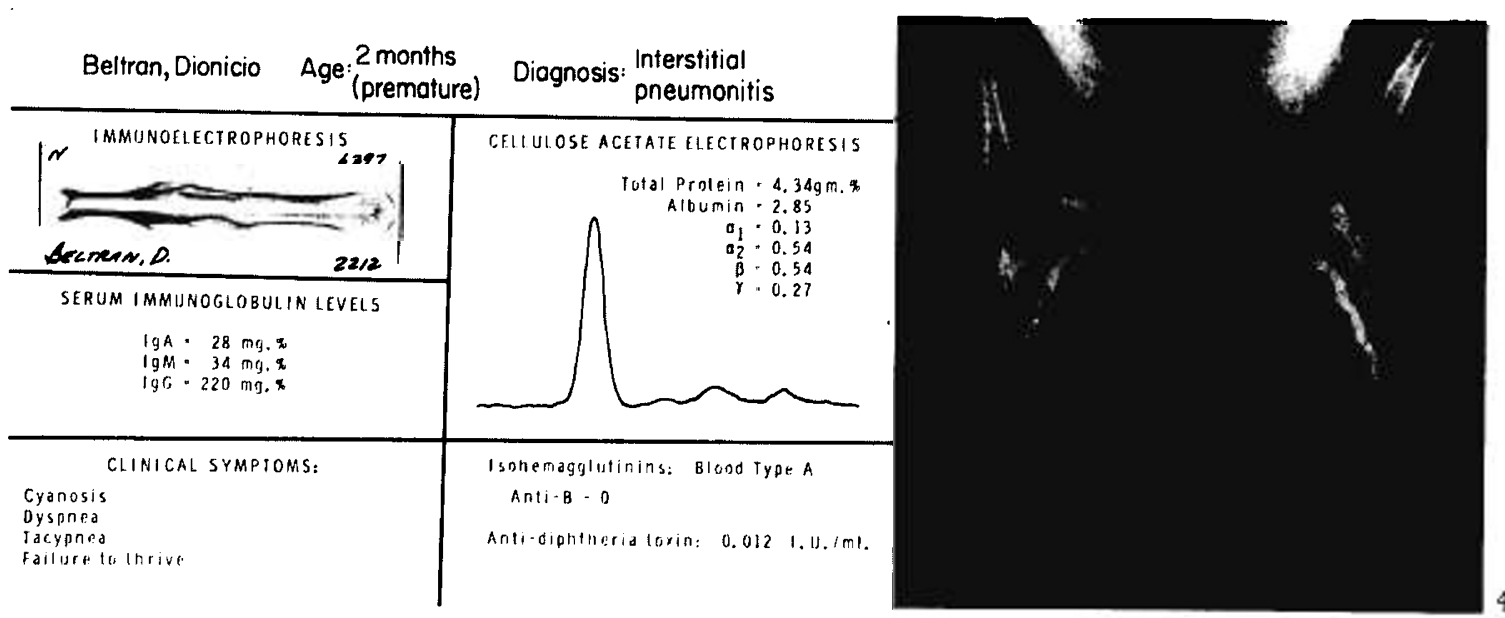

tion. On the 15th hospital day, an open lung biopsy substantiated the suspected diagnosis of pneumocystis carinii infection. Immediately after surgery, Dihydrostilbamidine therapy was given in a dose of $250 \mathrm{mg}$ per day. This was discontinued after the fourth day because of severe toxicity manifested as intense, lower abdominal cramping pain about four hours after the infusion. Pentamidine was obtained with FDA approval and this was given for ten days in a dose of 3.2 $g$ over the ten-day-period total. During the period of treatment, his fever slowly came down and his respiratory symptoms decreased. Surgery itself was very difficult as there was a great degree of alveolar capillary block and the pulmonary compliance was very low. The anesthetist had great difficulty bag breathing the patient because of this. Postoperatively, there was a great deal of respiratory distress, which was managed with a Bennett respirator and continuous use of oxygen.

On the 30th hospital day, just after completion of Pentamidine treatment, the patient suddenly developed coma. The clinical diagnosis was a small cerebrovascular accident, involving the pontine area. Over the next three days, the patient slowly came out of coma and was left with a residual stupor and signs of pseudobulbar involvement. He had difficulty swallowing and speaking.

The patient was discharged after interim treatment of a subdiaphragmatic abscess, much improved. $\mathrm{He}$ was beginning to cat and walk about. During his stay in the hospital, his Prednisone therapy was discontinued.

The patient, at present, is continuing to convalesce satisfactorily and is on no medication at all.

\section{Case 4, figures $4 A$ and $B$}

A two-month-old male infant was brought to the Uni- versity of Florida Teaching Hospital with a chief complaint of increasing respiratory distress and difficulty in feeding of approximately two weeks duration. This was the eighth child of a 28-year-old mother whose gestation lasted for eight months. Delivery was normal but the child developed respiratory distress six hours after birth which was treated by oxygen administration and supportive fluid therapy. The child improved and was sent home following several weeks of antimicrobial therapy for a mild upper respiratory infection. He was readmitted to the hospital at age one month with a respiratory infection which was treated with antimicrobial agents for two weeks. Because of the increasing respiratory distress and the diffuse nature of the infiltrate of process and $x$-ray, he was admitted to our service. The seven older siblings and parents were well and healthy. Admission showed pulse rate of 120 , respiratory rate of 84 , and a blood pressure of $70 \mathrm{~mm}$. The child was extremcly dyspneal with a weak cry and occasional rales were heard over the posterior portions of both lung fields. White blood count was 12,000 with 4,000 to 5,000 lymphocytes per $\mathrm{mm}^{3}$.

No organisms were cultured from the nasopharynx that were considered significant pathogens and repeated search for Pneumocystis carinii cysts were negative. At open thoracotomy the lungs were slightly inflammed and the pleural surfaces were clear. Lung biopsy showed an interstitial pneumonitis without any evidence of Pneumocystis carinii or cytomegalic inclusion disease. Supportive therapy, including high humidity, oxygen and parenteral fluids were offered. After two weeks, the baby's condition improved as evidenced by the decreased respiratory and pulse rates and weight gain. The child was discharged from the hospital three weeks after admission with increasing weight gain and a diminution in the extent of the infiltrative process in the lung. His local physicians confirmed a continued improvement in growth of the infant at home. 


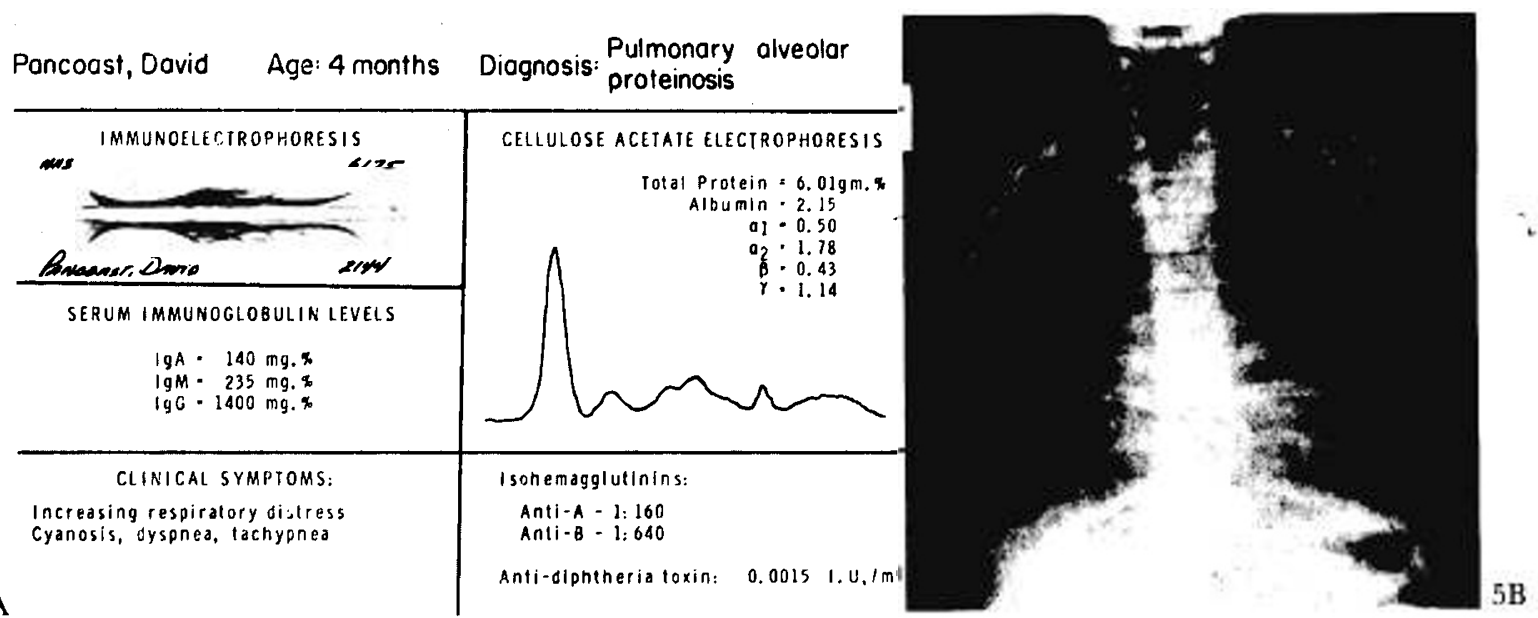

Ciase 5, figures $5 A$ and $B$

A three and one half month old male infant was admitted to the hospital with a chief complaint of increasing breathlessness and coughing. Maternal pregnancy and delivery was normal and the birth weight was seven pounds. A normal three year old brother and both parents were healthy. Normal development was arrested at age three months when signs and symptoms of an upper respiratory infection appeared. Antimicrobial chemotherapy was administered without change in the progression of respiratory distress.

A lung biopsy taken from the right middle lobe was originally interpreted as Pneumocystis carinii pneumonitis. X-ray and serum protein analysis are shown. No effect of pentamidine isothionate therapy upon his pulmonary disease was detected. The patient expired following worsening of his cyanosis and dyspnea. Sections removed at post mortem examination as well as material taken at thoracotomy were diagnosed as pulmonary alveolar proteinosis by Dr. A.A. Liebow, Yale University, New Haven, Connecticut, as well as the pathologists at San Diego, California and Gainesville, Florida. This material is presented to illustrate the difficulty in distinguishing the signs and symptoms of pulmonary alveolar protrinosis from those detected in patients with Pneumocystis carinii pneumonitis.

\section{Ubiquity of Pneumocystis carinii}

The detection of the organism as a pathogen in human discase or in experimental wild and domestic animals appear to be world wide [7-13] (tables I and II). Although formerly presumed to be an organism found in temperate climates, the detection of Pneumocystis carinii pneumonitis in the Congo, Central America, Middle East and Equatorial Pacific islands among
Table I. The worldwide distribution of Pneumocystis carinii is shown by the variety of countries with affected individuals.

Countries reporting Pneumocystis carinii pneumonitis

\begin{tabular}{ll}
\hline Australia & Italy \\
Belgium & Korea \\
Brazil & New Zealand \\
Canada & Norway \\
Chile & Poland \\
Congo & Spain \\
Denmark & Sweden \\
Finland & Switzerland \\
Germany & Union of South Africa \\
Hungary & United Kingdom \\
Iran & USA \\
Ireland & USSR \\
Israel & Yugoslavia \\
\hline
\end{tabular}

Table II. 'Natural' and 'experimentally induced' infection may be found in a wide varicty of animals. The significance of 'natural' infection in animal to human disease is not known.

Animal hosts for Pneumocystis carinii

1. 'Natural'
a) rats
b) dogs
c) guinea pigs
d) man
e) monkeys
f) sheep
g) goats

2. 'Experimentally induced'
a) suckling young and adult rats
b) suckling and adult rabbits
c) mice 
other examples, indicates that the organism is ubiquitous [14-20]. The mode of transmission is not well understood. Pandemics of the disease that occurred in nurseries in the middle European countries following World War II have been explained as duc to contact with carriers of the organism. Serological analysis of nursing personnel and their patients in nurseries using a complement fixation test indicate that active immune response of adult individuals may be related to the continued occurrence of Pneumocystis carinii infection among children [21-24].

If a similar increase in Pneumocystis carinii discase occurs in institutions concerned with the care of newborns under the conditions of deprivation that occur following wars then prophylactic measures may be of value and experience with such techniques should be revicwed.

The widespread distribution of the organism, its morphological characteristics, and the infrequent cmergence of the parasite as a pathogen has prompted scveral investigators to compare Pneumocystis carinii to Toxoplasmosis gondii. Direct demonstration, using dcfined biochemical characteristics of the organisms or serological cross reactivity data, however, is not available [13].

\section{Classification of the Parasite}

If we assume that the cysts found in the intra-alvcolar spaces are neither fungal in origin nor degradation products of injured tissues [25-33], then further analysis of Pnetumocystis carimii must await in vitro cultivation of the organisms. To date, this has not been accomplished. An explanation for this failure may be found in the pathological data obtained in animals and humans.

With few exceptions [5, 34] most studies have emphasized that the cysts are found primarily within the intra-alveolar spaces. The few organisms that have been detected within the pulmonary parenchyma have been shown to be within phagocytic cells. It is of interest to note that at autopsy the cysts are rarely detected in the hilar lymphatic tissue despite the protracted course of the disease. These findings would indicate that the metabolic requirements for this organism are restricted to conditions prevailing in the environment of the alveolar spaces. The nutritional and biochemical environment of the alveolus, well studied by several workers [35], might serve as a guide for selection and preparation of the nutrient media which would support growth of the organism.

The disadvantages of not having the organism in relatively pure form are numerous. Serological analyses of Pneumocystis carinii infections necessary for the study of epidemiology and attempts at prophylaxsis in nurseries and as well as other sources of contagion and animal vectors has been difficult because of the inability to obtain a pure source of antigen from infected lungs [10]. Animal sources of Pneumocystis carinii have been poor sources of serological reagents $[1,10]$. It has been postulated that serological specific strains of the parasite are related to the species under study. Alternatively, the difficulties encountered may be due to the reactions of lung tissue contaminants of the experimental animal with human serum which must be removed before the measurement of the reaction of Pneumocystis carinii organisms with serum antibodies $[10,22-24,36-43]$. Finally, the mode of transmission of the parasite, its extrapulmonary morphology, and its metabolic requircments are unknown. Accurate data regarding these important deficits in our knowledge await successful in itro culture of the parasite.

To date, the only evidence that the 'cysts' represent viable organisms is their constant presence and uniform morphologic characteristics in the lungs of patients and experimental animals with this disease. The susceptibility of the organisms to pentamidine [44-52] and their morphology $[5,11,13,23,32]$ is consistent with classification as a protozoan organism, but this data only constitutes indirect evidence.

\section{Pathology}

\section{Tissue Specificity of Pneumocystis carinii}

With onc exception recorded to date [34], the parasite has not been detected in other than pulmonary tissue. The primary lesion initially is in the pulmonary alveolar spaces. Later, cysts are found in lesser numbers in surrounding supporting structures such as the alveolar septa. Small numbers of organisms are detectable in the exudate of bronchioles and larger airways. These extra-alvcolar organisms are mostly extracellular or within phagocytic cells and are infrequently found in the airways. This remarkable specificity is found in both natural and experimental infections of animals as well as humans [5, 7, 9-13, 30-32, 54-63]. Careful scarch of other organs in heavily infected individuals has failed to demonstrate these organisms in extra pulmonary tissues. It is inferred from the report of PAVLica [62] that the organisms may have penetrated the placenta. In this report, good evidence is presented to show an in utero infection can occur with formation of the characteristic adult pulmonary lesion. There was no evidence in this case that placental infection was the cause of the in utero pulmonary infection. Of interest was the absence of Pneumocystis organisms in other tissues of the infected fetus.

This narrow range of tissue infectivity may explain two aspects of the problem presented to the physician 
and investigator by Pneumocystis carinii. The first is the apparent dissociation of signs and symptoms exhibited by affected individuals. Patients with intense cyanosis (arterial oxygen saturation values of $70 \%$ or less) and $x$-rays indicating bilateral diffuse disease may have normal temperature and normal peripheral leukocyte counts as well as few complaints of illness. This absence of constitutional symptoms or reliable physical signs may be related to the absence in significant number of Pneumocystis from sites other than the pulmonary alveolar spaces. Lung necrosis, significant extra pulmonary fluid accumulation, and other evidence of inflammation or dysfunction of this organ have not been reported.

The inability to cultivate this organism in vitro may be explained in part by the observed tissue specificity of Pneumocystis. It is possible to explain the inability to grow Pneumocystis carinii outside of the susceptible host by assuming that the unique metabolic characteristics of the alveolar space have not been duplicated in vitro. In addition, since one of the predisposing characteristics of the susceptible host is a diminished capacity for antibody synthesis, the antibody content of the serum supplement, representing pooled sera, of the culture media may act as an inhibitor. One source of tissue culture nutrition without antibodies, precolostral calf or pig sera, may be a useful reagent in studying techniques to grow Pneumocystis carinii.

\section{Morphological}

In a discussion of the pathological lesion of Pneumocystis carinii pneumonitis, three factors should be emphasized. The first is that the disease is due to a slowly growing organism $[10,11,54-56]$ which affects both lungs rather evenly although there may be a more intense reaction surrounding the hilar areas. The second is the remarkable tissue specificity of the parasite. Initially, the pathological lesion is predominately an intra-alveolar exudate provoked by the parasite. The fibrosis and consolidation is probably a secondary reaction to the intra-alveolar exudate. The third is the nature of the infiltrative cells induced by the parasite. The absence of tissue necrosis and the slow devclopment of the lesion are paralleled by the cell types observed. Mononuclear cells including histiocytes, lymphocytes, and plasma cells are the most frequent inflammatory cells observed. In the cases with an underlying immunological deficiency, plasma cells are not observed $[2,5,32,43,58,61,63,64]$. Much of the confusion regarding the term 'interstitial plasma cell pneumonia' has been attributed to the careful observation of investigators studying the same disease provoking different cellular reactions in various individuals. This problem was resolved when the heterogeneity of the hosts was considered. The absence of plasma cells in the pulmonary infiltrate in individuals with immunological deficiency syndromes was also consistent with their state of depressed antibody biosynthesis. Analysis of the sera of such individuals revealed no antibody to Pneumocystis antigen [43, 64]. To account for the reaction of different hosts, Pneumocystis carinii pneumonitis would seem to be the best designation for this disease.

The gross pathological findings are similar when taken from lung biopsy material, experimentar animal models, and autopsy tissue. Both lungs are similarly involved. There is little or no visceral or somatic pleural reaction. The parenchyma is stiff, relatively avascular and may show small local areas of emphysematous change. This hyperinflation is presumably the result of lung rupture secondary to air trapping. There is no lung necrosis and the fibrotic changes are usually most intense in the perihilar area. Hilar lymphadenopathy is usually not present.

The intra-alveolar exudate containing the Pneumocystis cysts seems to be the earliest lesion [7, 9-11, 56, $59,61,63]$. The exudate contains some polymorphonuclear leukocytes, but the predominant cell type is the histiocyte, lymphocyte and plasma cell. The intra-alveolar exudate is quite distinctive. At low magnification, conventional staining shows a lace-like appearance to the round balls of eosinophilic material which is also positive to periodic acid Schiff base. This latter finding is consistent with the presence of glycoproteins in the exudate. Presumably, fibrinogen is a major component of the exudate but this has not been demonstrated with immunofluorescent reagents. Marshall [50] reported that the serum concentration of IgM molecules was elevated during the acute phase of the disease. The carbohydrate content ( 7 to $10 \%$ ) of $\operatorname{Ig} M$ [65] may offer another source of Pneumocystis inflammationinduced molecules that might account for the positive stains for carbohydrate.

The cysts observed with several stains such as Giemsa and Gram Weigert are best demonstrated by a silver impregnation technique $[2,66,67]$. They are found in the intra-alveolar spaces and occasionally in the septa walls within paghocytic cells. The bronchiolar and large airways are usually clear although they may contain scanty exudate with few Pneumocystis cysts. The detection of bronchiolar cysts and exudates is not a constant finding $[30,31,60,63]$.

Most of the respiratory pathophysiology can be rerelated to the lesion of the alveolar septa. Although little experimental data is available, a likely explanation for this finding may be gleaned from the growth characteristics observed from clinical material and experimental animals. Pneumocystis carinii would seem to be best described as an organism of low virulence. The full pathological lesion induced by this parasite devel- 


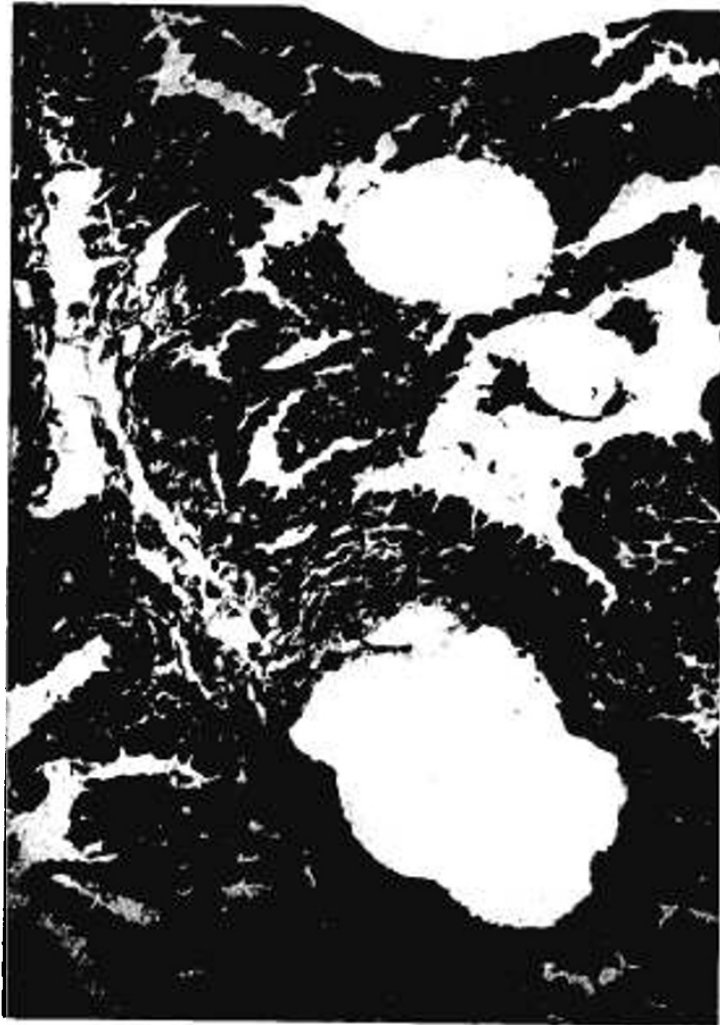

Fig. 6.A. A $\mathrm{H}$ and Escction $(440 \times)$ shows the progression of the morphological lesion. The intra-alveolar exudate provokes a fibrotic reaction in the septa. Obliteration of the alveolar spaces and the thickened alveolar septa combine to produce an inadequate functioning lung.

$B$. Direct demonstration of the parasite at its intraalveolar site by silver impregnation stain (Gomori).

ops very slowly. At least three to six weeks are necessary for the disease to involve most of the lung parenchyma $[4,6,11,21,32,54,55]$. Since it is almost exclusively an intra-alveolar parasite, the surrounding pulmonary alveolar septa would be expected to show the most tissue reaction and fibrosis. The inflammation of the alveolar septum and the inability of the parasite to invade other tissues presumably causes the characteristic metabolic alteration, alveolar-capillary block. The characteristic slow growth of the organism probably permits a continued fibrotic degeneration of the septal walls without causing death to the host until the lesion has involved most of the lungs.

The mechanism of spread of the organism throughout the lung parenchyma is unknown. However, the increased number of organisms seen at the hilar areas as well as the predominance of the most fibrotic reac-

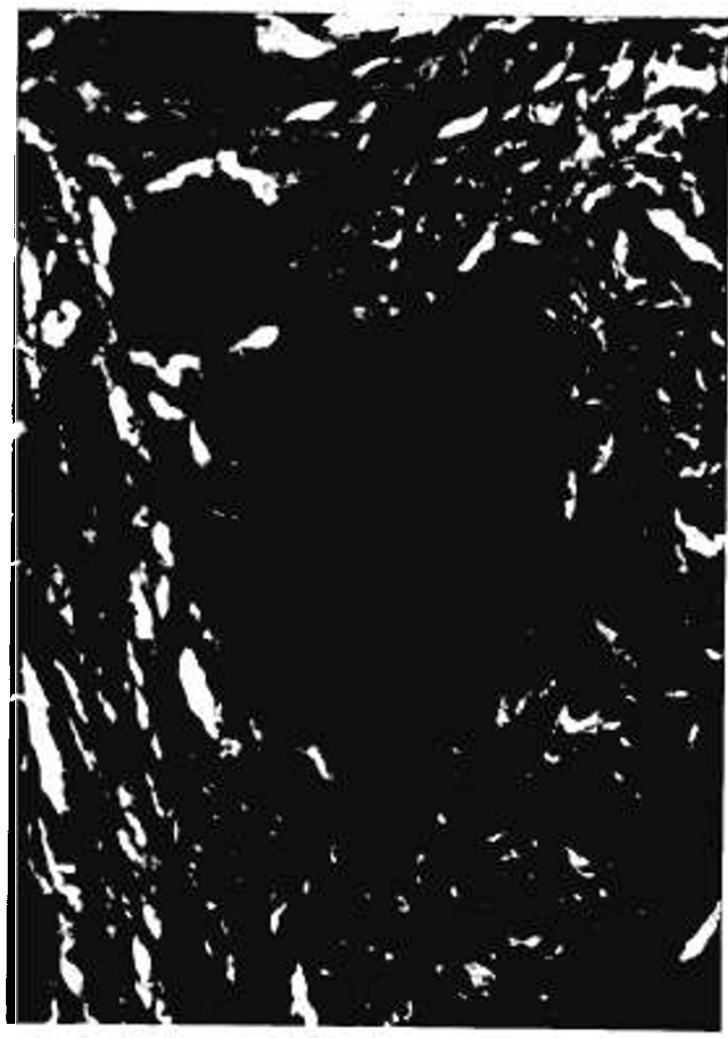

tion at this same location may offer some explanation for the pulmonary dissemination of Pneumocystis [30, $60]$. The pneumonitis is induced primarily by the local proliferation of Pneumocystis organisms. The irritation and inflammation that occurs results in coughing. The cysts are expelled into the larger airways and fall back into other airways where they are swept into the alveoli. There, new inflammation occurs. The predominance in the dorsal regions of the lungs in younger infants, noted by some workers [60], is consistent with this mode of intra-pulmonary spread of Pneumocystis in patients constantly in the supine position.

As the disease progresses, the fibrotic reaction results in the fusion of the septa with the intra-alveolar exudate and the obliteration of the alveoli. The progression of these lesions is shown in figures $6 \mathrm{~A}$ and $\mathrm{B}$. The thickened alveolar septa as well as the relatively clear airways are also well illustrated in this figure. As one would predict, the increasing obliteration of alveolar spaces is accompanied by increasing cyanosis and eventually causes death due to extreme hypoxia $[4,5,8,30$, $32,57,63]$.

\section{$X$-ray Findings}

There is no distinctive roentgenological characteristic to identify the interstitial pneumonitis induced by Pneumocystis carinii. As shown in the case material, 
similar $x$-ray findings are found in individuals with interstitial pneumonitis of infancy $[4,6,24,27,57,59$, $68,80]$ and pulmonary alveolar proteinosis $[24,78-83]$. The altered transmission of the $x$-ray is due to the thickened interstitial tissuc and obliteration of the alveolar spaces. The pathological process excited by this pathogen involves most, if not all, the lung parenchyma. An understanding of the pathophysiology of this discase should provide a high index of suspicion to physicians confronted with the characteristic $x$-ray findings early in the disease.

An explanation for the observation that the inflammation and fibrosis is more prominent in the dorsal portions of the lungs of prematures may be inferred from the pathophysiology [59]. This disease progresses slowly and causes much debilitation. For a variable but prolonged period, the affected individual is lying on his back. The cysts that are expelled into the larger airways would be expected to fall back and reenter the dorsal parenchyma. This finding should be looked for to confirm its reliability as a diagnostic lead.

The interstitial scarring occurs bilaterally and most of the lung parenchyma is affected. The perihilar areas appear to be more opague than the rest of the parenchyma. This radiological finding has been correlated with gross pathological studies and is due to additive effects of the increased scarring in this area and to the opacity of the major vessels and airways.

Rupture of the ventral lung parenchyma with resultant pneumomediastinum and/or pneumothorax and subcutaneous emphysema $[20,67,76,84]$ is an unusual complication detected late in the course of the disease, and then mostly in neonates and infants.

Without an associated disease, there is little hyperplasia of the pulmonary lymphoid tissue. Hilar lymphadenopathy is not a constant feature of this disease. This lack of reactivity may be due to the defective immune status of these patients or to the low invasiveness and absence of extracellular products of the organism.

In summary, the overall x-ray finding of Pneumocystis carinii is not directly distinguished from other diffuse pneumonias characterized by scarring of the interstitial septa and obliteration of the alveolar spaces [84-88]. The process is diffuse and bilateral at the time that the symptomatology provokes medical attention. The growth charactcristic, low level of virulence of Pneumocystis carinii and debilitation of the affected individual, may account for the more advanced inflammation in the ventral portions of the lungs. The compensatory emphysematous changes occasionally result in adventitious air in the mediastinum, pericardium, and subcutaneous tissues.

$\mathrm{X}$-rays, characteristic of the discase, are illustrated in the section devoted to case material.

\section{Demonstration of the Organism}

Direct demonstration of Pneumocystis cysts is necessary for a precise clinical diagnosis. Ancillary laboratory data may define an immunological deficiency syndrome. They include immunoglobulin levels in serum and peripheral lymphocyte count. An estimation of the altered respiratory physiology as assessed by $\mathrm{x}$-ray examinations and pulmonary function studies, together with the history and physical examination, constitute indirect evidence relating to the diagnosis. Although several workers have reported that demonstration of the cysts is possible in sputum, antemortem $[37,85,89-96]$ even a careful search usually fails to reveal the organism in most instances [51, 84]. Identification of Pneumocystis carinii in sputum early in the course of the disease, however, has been accomplished in several cases. There is as yet no data on the percent of positive sputum analyses in proven cases of Pneumocystis carinii. Some ideas of the frequency with which the organisms are found in the sputum may be derived from the study of Thigs and Janssens who recorded the number of cases in which Pneumocystis carinii could be identified within the lumen of the bronchioles among 15 autopsies performed upon infants. These workers found intra-bronchiolar cysts [18] in one third $(5 / 15)$ of the cases. In two instances, the diagnosis was achieved by lung biopsy after intense search for the organisms in sputum using specific stains had failed.

Lung aspiration by needle biopsy has proven successful in identification of the disease in several instances $[97,98]$. In each recorded instance, lung tissue removed by this method revealed the lesion in proven cases of Pneumocystis carinii pneumonitis. This success is probably best explained by the diffuse nature of the disease. Of interest is the report, kindly made available to us [92], describing a fatal pneumothorax following needle aspiration of a lung infected with Pneumocystis carinii. Attempts at decompression of the hemipneumothorax were unsuccessful. At autopsy, the stiff and fibrotic lung showed no tendency to close over the needle tract. Other reports have indicated that direct visualization of the pulmonary parenchyma at thoracotomy results in a lower morbidity and mortality than needle biopsy [99]. The gross pathological finding of a stiff, noncollapsing parenchyma suggests that tissue should be obtained under direct visualization to avoid this complication. No ante-murtem demonstration of Pneumocystis carinii cysts outside of the respiratory tract has been reported.

\section{Host-parasite Relationship Characteristic of Pneumocystis carinii pneumonitis}

The case material has been divided into three groups in order to identify more clearly the most common fac- 
tors reported to predispose to Pneumocystis carinii pneumonitis. Those cases were chosen for review provided with clinical, laboratory, and morphological data in addition to a positive identification of the organism.

Intrauterine infection. The first group, though comprising only three cases, nevertheless is most important. In these cases, infection undoubtedly was transmitted to the individual during intrauterine life $[20,62,100]$. Typical pathological characteristics of Pneumocystis carinii infection were detected in a full term macerated fetus [62] and a two-day-old infant with Down's Syndrome [20]. In the third report, a ten day old infant died with diffuse pneumonitis with the typical pathological findings of Pneumocystis carinii infection [100]. Data derived from studies of experimental models and extrapolation of clinical symptomatology, lung biopsies, and pathological studies provided strong evidence that the cyst does not occur as a postmortem contaminant $[4,9-11,21,22,30,31,36-39,42,54-57,61$, $62,81,86,91,98]$. Further, the lesion requires at least two to three weeks for the typical pathology to develop. Therefore, we must presume that the infection was acquired in utero. No reports indicate maternal ingestion of drugs which have been associated with a predisposition to Pneumocystis carinii infection or of exposure to infected individuals. Unfortunately, neither serological analysis of the maternal serum nor other evidence of maternal infection have been presented. The most plausible explanation for the instances of neonatal disease is that there was an intrauterine infection due to bloodborne transmission of the parasite. Although there are several references to the demonstration of Pneumocystis carinii cysts at extrapulmonary sites, most morphological studies using human autopsy ma-

Table III. The unequal distribution of cases of Pneumocystis carinii pneumonitis in newborn and premature infants in a city is shown. The frequency of cases in 3 institutions as compared to the remainder of Pneumocystis infections was not related to the type or number of patients at each institution.

Early hospitalization history of 120 infants with Pneumocystis carinii in Hamburg

* Nursery homes for newborns . . . . . $62 \%$ Small clinics for infants . . . . . . . . $24 \%$ Cared for at home . . . . . . . . . . $9 \%$ Various institutions . . . . . . . . . $5 \%$ * 3 out of 11 hospitals accounted for $85 \%$ of these cases

After: von HaRnaK: Mschr. Kinderheilkunde 108: $159(1960)$

10 Pediat. Res., Vol. 1, No. 2 (1967) terial or experimental animals have failed to find the parasite in other tissues. These three instances of fetal infection should provide the impetus for designing an experimental model to study this process of transmission. Such an experimental model would permit a more accurate evaluation of the development of the pathological lesion and the viability of the parasite in the various body fluids.

Host without demonstrable predisposing lesion. The next group of patients accounts for most of the cases of Pneumocystis carinii infection. The author has distinguished two clinical conditions which are important in understanding the appearance and distribution of the disease.

The first factor, contagion, is the most important etiological mechanism operative in this group. The mode of spread of Pneumocystis infections in 'normal' host is presumed to be due to exposure of an individual to a high concentration of the parasites in the air. Such an environment is readily attained in newborn nurseries. This may result in the unusual distribution of cases within the institutions of one city (table III) [104]. Epidemics such as the one illustrated in table III have accounted for the death and possible permanent disability of thousands of children. Nurseries designed to care for abandoned or disabled children must contend with Pneumocystis carinii infection as a significant cause of perinatal death (table IV) [20, 100]. Our understanding of the factors initiating such epidemics has been limited by the few reliable techniques for identifying the organism. Using a serological analysis, a high incidence of positive reactions has been detected in workers and nurseries [24, 36-39, 41, 101]. There is yet no other reliable method of identifying a carrier

Table IV. The importance of Pneumocystis carinii pneumonitis as a cause of death of infants admitted to a hospital in Iran is shown.

Cause of death of 40 infants in foundling home and newborn nursery

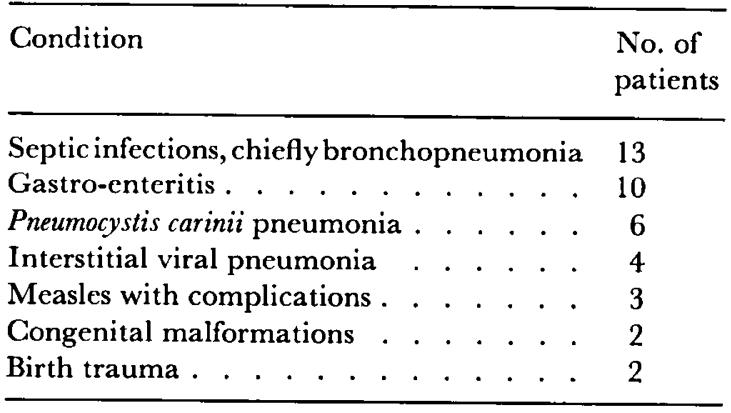

After: Post et al.: Arch. Dis. Childh. 39: 35 (1964) 
state or subclinical infection since the parasite has been reliably identified only in the lungs or sputum of severely infected hosts. Indirect evidence of airborne transmission of the parasite as the major cause of spread has been inferred from the effectiveness of sterilization of the air with ionizing radiation in affected hospitals $[22,95,103,104]$. Although it has been difficult to prove, a plausible explanation for the start of these epidemics is that the initial infections in these nurseries originated in prematures with poor nutrition (so-called 'dysplastic' infants). The term 'dysplastic' describes any debilitated premature infant regardless of etiology. Many instances of Pneumocystis carinii infection occur sporadically in malnourished premature infants $[8,16$, $17,21-23,69-71,77,83,99,105-117]$. In these cases, the incompletely developed immunological response of full term newborns or prematures and exposure to infected infants in a closed environment have been assumed to interact synergistically to produce diseaes. Many instances of so-called infectious diseases unique to newborn immunological immaturity have undergone reclassification as a result of additional clinical evidence. The predominance of severe and fatal infection with saprophytic bacteria has, in many instances, been shown to have been due to an unusual exposure of prematures and newborns to these organisms of low virulence because of contaminated ventilation systems [118]. In the future, quantitative techniques for the demonstration of Pneumocystis carinii in other than affected lungs may permit a more comprehensive understanding of factors important in contagious spread of the disease in nurseries. In summary, the presence of one or more 'dystrophic' prematures with Pneumocystis carinii infection has been postulated to be sufficient to initiate an epidemic in a nursery. Factors sufficient for contagion, such as a high concentration of airborne parasites, may then result in a spread of the infection to normal prematures and full term newborns.

Of interest are recent reports of the contagious nature of the disease in normal full-term newborns and young adults [119-121]. Thus, with a certain level of exposure, an otherwise healthy newborn or adult may contract the disease. This observation has more than theoretical importance because it should influence the judgment of physicians responsible for the care of immediate contacts of patients with Pneumocystis carinii pneumonitis.

\section{Newborn and Premature Infants}

The following cases were analyzed because sufficient pathologic, clinical, and laboratory data were included in the reports $[3,8,15,16,20,62,69-71,77-79,99$,
105-107, 109-112, 114-117, 121, 122]. In addition, data from the following sources were also used to study newborn host-parasite relationships [122-135]. Most of the individuals with Pneumocystis carinii pneumonitis without apparent previous disease have been newborns and prematures. Some of the characteristics of these cases are shown in table V. For many of the cases, contagion was the most likely explanation for the induction of Pneumocystis infection. A history of intimate contact with infected children, usually within a hospital or nursery, was present in many cases $[8,15,16,20]$. There are, however, documented incidences of infants with $P$ neumocystis infection detected as sporadic, isolated instances. In these cases, there was no known contact with infants suffering with Pneumocystis infection. A more careful scrutiny of the clinical history in these patients arouse the suspicion that the term 'without predisposing disease' may be misleading. The clinical history of many of these newborn cases reveals that antimicrobial chemotherapy was administered at least three weeks before the development of clinical symptoms of Pneumocystis infection (table V). Three weeks was chosen as a critical period to identify these individuals because this period seems to be the minimal incubation time for the clinical expression of Pneumocystis disease. Antimicrobial chemotherapy, per se, has been shown to be sufficient experimental manipulation to induce Pneumocystis infection in a small percentage in newborn and adult experimental animals [9-11, 54, 56]. A similar effect of antibiotics in human hosts may also occur. It is significant to note that many of these cases were treated with antibiotics for respiratory infections [8, 114]. Another factor to consider whether these newborns were indeed 'normal' may be extracted from other clinical observations. The association of pulmonary infectious disease predisposing to Pneumocystis carinii pneumonitis was first observed by CHAGAs [135]. Since then, several infectious diseases have been associated with Pneumocystis infection [17-19, 113]. The pathogenesis of this predisposition to Pneumocystis infection is not clear. One possibility is that chronic injury to the pulmonary parenchyma may be sufficient to permit suprainfection with Pneumocystis. The clinical symptoms that provoked care for these preceding infections were not typical of Pneumocystis pneumonitis and have been presumed, for the purpose of this report, to be different illnesses.

In summary, a critical evaluation of the host-parasite interaction operative in the induction of Pneumocystis carinii pneumonitis in newborns and prematures reveal that many individuals are not truly 'normal'. Infected individuals are highly contagious for other infants in institutions or closed environments and may serve as a reservoir of infection for otherwise healthy newborns. Pre-existing respiratory infection treated with anti- 
microbial agents may be sufficient to permit the latent Pneumocystis infection to bccome life threatening. Analysis of sporadic cases of Pneumocystis infection in newborns reveal that many of these 'normal' individuals have received antimicrobial therapy for respiratory infections at least three weeks prior to detection of their clinical disease. The possibility of these two factors, antibiotics plus a significant respiratory infection, as sufficient conditions to activate a latent Pneumocystis carinii infection in a few newborn and prematures, should be considered.

Of interest is the occurrence of Pneumocystis carinii pneumonitis in adults without obvious predisposing disease or a significant history of chemotherapy preceding the illness (table VI). There are four such reported cases in the literature $[60,120,136,137]$. In the case reported by WANATABE [120], contagion would seem the most likely cause of the infection in the so-called 'normal' adult. Perhaps a more careful search among pathologic material of adults who have died of obscurc lung disease may reveal that occurrence of Pneumocystis infection is not as rare as formerly thought in so-called 'normal' adults.

\section{Infectious Diseases}

Several infectious discases have been associated with a high incidence of concomitant Pneumocystis carinii infection. The most prevalent infectious disease associated with Pneumocystis carinii pneumonitis has been cytomegalic inclusion disease $[5,15,69,89,99,122$, 129, 138-145]. In many cases, congenital cytomegalic inclusion disease has been the predisposing disease for Pneumocystis carinii infection in newborns. The diffuse nature of the cytomegalic virus infection and its accompanying multi-system dysfunction result in a chronically ill individual. This type of debilitation seems to be sufficient to induce the clinical expression of Pneumocystis. Cytomegalic inclusion disease is another example of a latent infection which may be activated in the adult with a lymphoreticular malignancy and/or chemotherapy. Cytotoxic chemotherapy administered for other therapeutic indications is also associated with a high incidence of Pneumocystis infection. Of interest is the occurrence of these two diseases in adults with lymphoreticular malignancies and adults receiving immunosuppressive chemotherapy for renal transplantation [140]. Congenital and disseminated tuberculosis, pulmonary cryptococcus and some bacterial pneumonias have also been reported to predispose to Pneumocystis infection [128, 145, 146]. As will be emphasized further, a diffuse pulmonary disease in a patient with a pre-existing infection should be sufficient grounds to excite the investigative energies of physicians to scarch for Pneumocystis infection. It would seem that any chronic infections, especially those involving
Table V. Clinical characteristics of newborn and premature infants with histologically verified Pneumocystis carinii pneumonitis are reviewed.

Clinical characteristics of newborn and premature group with Pneumocystis carinii pneumonitis ( 74 cases)

Age at death -4.2 months (8 days -18 months)

Age at onset -3.4 months

Duration of illness - 3-5 weeks

Previous disease - 28

Previous treatment with antibiotics - 23

Presenting symptoms (38 descriptions)

1. dyspnea $\quad 36$

2. anorexia 23

3. cough 20

4. tachypnea 18

5. cyanosis $\quad 18$

Clinical signs (38 descriptions)

1. dyspnea 36

2. cyanosis 34

3. tachypnea 34

4. cough $\quad 10$

5. fever 8

6. rales 8

Laboratory data

\begin{tabular}{llr} 
1. WBC - & $>10,000-10$ \\
& normal-2 \\
& $<5,000-2$ \\
2. X-ray - & diffuse, bilateral infiltrates & $25 / 25$ \\
& adventitious air & $4 / 25$ \\
\hline
\end{tabular}

Table VI. The similarities between the clinical disease of Pneumocystis carinii pneumonitis in individuals with primary immunological deficiency syndromes and 'normal' patients is shown. Note the high incidence of preceding antibiotic treatment in this group. The time course of the progression of the disease in these individuals was similar to other groups of patients.

Analysis of clinical characteristics of Pneumocystis carinii pneumonitis in patients with $1^{\circ}$ immunological deficiency syndromes ( 31 cases)

\begin{tabular}{llr}
\hline Age of patients & 3 months -7 years \\
Number receiving & chemotherapy & $18 / 22$ cases \\
& antibiotics & $17 / 22$ cases \\
& corticosteroids & $3 / 22$ cases \\
Duration of symptoms 3-6 weeks & \\
\hline
\end{tabular}

multi-organ systems, can predispose to Pneumocystis. Administration of cytotoxic, corticosteroid, and/or antimicrobial agents to such patients increase the risk of activation of this latent infection. 


\section{Immunologic Deficiency Stutes}

Primary immunologic deficiency states. That immunological deficiency states could predispose to Pneumocystis carinii infection was first reported by BURKE et al. [64]. The following cases $[48,50,51,53,64,78,82,109-111$, $132,134,149-155]$ are cited to study the clinical characteristics and host interaction mechanisms in patients with primary immunologic deficiency syndromes with Pneumocystis infection. Primary immunologic deficiency syndromes are defined as those states of clinically or laboratory defined immunologic deficiency which are unassociated with the administration of cytotoxic agents or are consequent to a known disease process.

Pneumocystis carinii pneumonia occurs in individuals with primary immunologic deficiencies. This association, first reported by Burke et al., has been now well documented in the literature [64]. It would seem that immunologic deficiency syndromes of all types reported are associated with Pneumocystis carinii infection. Several cases of Pneumocystis infection reported as occurring in 'normal' individuals may have been, in fact, individuals with hypogammaglobulinemia [70, 109].

The association between primary immunologic deficiency syndromes and the absence of plasma cells in the pulmonary infiltrates of some patients with Pneumocystis infection is well known [43]. The difficulty in detecting serum antibody to the parasites in patients initially studied in this country with Pneumocystis infection and the absence of plasma cells in autopsy material of these patients were directly correlated as the inability of these individuals to produce antibodies to other infectious agents. In these cases, the morphological lesion with its alveolar scarring is quite comparable to the histology observed in tissues from individuals with 'normal' immunological function with the exception of the absence of plasma cclls in the infiltrate (see case material).

Pneumocystis carinii pneumonitis and immunological deficiency can occur at any age during the coursc of a primary immunologic deficiency disease and is associated with deficiency states of all types [144].

It should be emphasized that a history of antimicrobial chemotherapy can be found in the majority of patients with Pneumocystis infection and immunologic deficiencies (table VI). It is not clear if this is a direct association since one would expect that such individuals would be treated with antimicrobial agents quite often. Nevertheless, such an association is emphasized for two reasons: 1. Patients with chronic disease and induced secondary immunologic deficiencies also have a similar association with Pneumocystis infection. 2. Experimentally, the disease may be induced in a small fraction of some animal species treated with antibiotics for prolonged periods. This should be a consideration in deciding whether a patient with an immunologic deficiency syndrome should receive prophylactic antimicrobial chemotherapy or replacement therapy with gamma globulin. Parenteral administration of gamma globulin, with its attendant difficulties, would seem to be a therapeutic approach least likely to permit emergence of the latent Pneumocystis infection.

Another intercsting point to be considered in discussing patients with primary immunologic deficiency syndromes and Pneumocystis infection is the possibility that the true incidence of congenital immunologic deficiency states is masked by supervening Pneumocystis infection. Survey of the literature of patients in the newborn and young infant age group who have been reported to have Pneumocystis infection reveals that many of them may have had immunologic deficiency syndromes $[70,78,98,109,110,149,151]$. Autopsy findings such as diminished lymph node tissue, absent thymus, and low serum immunoglobulins arouse the suspicion that many so-called 'normal' newborn and prematures or isolated cases of the sporadic variety may have been, indecd, examples of Pneumocystis infections in patients with immunologic deficiency syndromes. The finding of Pneumocystis infection at autopsy should drive the pathologist and physician to seek evidence of immunologic deficiency syndrome. Such evidence, of course, has important considerations in genetic counseling as well as other items of interest for the investigator.

Secondary immunological deficiency states predisposing to Pneumocystis carinii pneumonitis. In this category, clinical and pathological data of patients with altered immune reactivity secondary to therapeutic agents are analyzed $[17,33,72,75,78,80,89,96,97,139-141,144,146$, 150, 157-174]. Patients with lymphoreticular malignancies and/or patients who have been treated with immunosuppressive drugs and later developed Pneumocystis carinii pneumonitis constitute the majority of cases. Other patients with a significant previous disease prompting immunosuppressive chemotherapy prior to the development of Pneumocystis carinii infection are also included. In all these cases, there is a consistant pattern of predisposing disease and emergence of the Pneumocystis organism as a pathogen. As can be seen in table VII, the list of chronic diseases that have terminated with Pneumocystis carinii infection is inclusive of much of medical pathology. Not included in this list are two cases of cyclic neutropenia in two young children in which the diagnosis of Pneumocystis infection was ascertained by lung biopsy and post mortem analysis [172]. It is predictable that examples of most chronic diseases will be shown to have been associated with an altered host reactivity so as to permit infection with Pneumocystis. The one characteristic common to 
these cases of Pneumocystis infection is that most, if not all, of the subjects received immunosuppressive and/or antimicrobial chemotherapy during the course of their illness prior to clinical detection of Pneumocystis infection. Of interest is the apparent high frequency of cortisone and cyclophosphamide treatments and Pneumocystis infection. Cyclophosphamide and cortisone are particularly efficient in inducing Pneumocystis infection in rats $[54,175]$. The relatively low toxicity of this former drug, as compared to other antimetabolites, may permit longer survival of humans and animals and, therefore, induce a high incidence of Pneumocystis infection.

Of 68 cases studied in the literature, corticosteroids were mentioned as therapeutic agents in 53 patients. The disease that prompted the corticosteroid therapy ranged from overzealous replacement therapy in adrenal cortico-virilizing syndrome to Hodgkin's disease. The former had not been noted to be coincident with an immunological deficiency state when replacement therapy was accurately gauged to meet the patient's requirements although acute infectious disease may be poorly tolerated. Hodgkin's disease and multiple myeloma, however, have been shown to depress the delayed skin reactivity and antibody formation respectively to various antigens [173]. Although several investigators have searched autopsy material, documented Pneumocystis carinii infection in patients with Hodgkin's disease has not been identified prior to the use of chemotherapy, both cytotoxic and/or antimicrobial agents, although the disease has been a significant factor as a causc of newborn morbidity for at least fifty years [126]. It would scem, therefore, that both an altered reactivity duc to the lymphoreticular malig. nancy and the immunosuppressive and/or antibiotic agents are necessary for the activation of Pneumocystis with high frequency. Some idea of the incidence of Pneumocystis infection as a complication of lymphoreticular malignancy may be surmised from the report of Robinson et al. [136]. Of two hundred and three autopsies of lymphoreticular malignancy examined, two cases of Pneumocystis infection were discovered. One would expect, that as supportive and anti-tumor measures increase in their therapeutic index, the incidence of latent infections, such as Pneumocystis carinii, will increase. A similar study (table VIII) reveals a slightly higher incidence of Pncumocystis infection in patients with lymphoreticular malignancies. This higher incidence may reflect a result of more efficient anti-tumor therapy with a longer survival. In contrast, ULTMANN et al., revicwing clinical and pathological data of 60 autopsied cases of lymphatic leukemia failed to detect this disease [174]. Other factors influencing host resistance to Pneumocystis may not be evident as yet.

Immunosuppressive chemotherapy, per se, is sufficient to induce Pneumocystis carinii infection. Examina-
Table VII. Clinical Characteristics of patients with Pneunocystis carinii pneumonitis and $2^{\circ}$ immunological Deficiency (68 cases) (ages: 3 months-78 years)

Etiology of $2^{\circ}$ immunological deficiency

\begin{tabular}{ll}
\hline Disease & $\begin{array}{l}\text { No. of } \\
\text { patients }\end{array}$ \\
\hline
\end{tabular}

Rheumatoid arthritis . . . . . . . . . 1

Alber's Shonberg . . . . . . . . . . 1

Hemophilia . . . . . . . . . . 2

Bilateral nephrectomy . . . . . . . . 2

Wegener's granulomatosis . . . . . . 1

Thrombotic thrombocytopenia purpura . 1

Pulmonary cryptococcosis . . . . . . . 1

Hodgkin's disease . . . . . . . . . . 5

Henoch Scholein's disease . . . . . . . 1

Rheumatic fever . . . . . . . . . . . 1

Nephrosis . . . . . . . . . . . . 2

Hand-Schuller-Christen disease . . . . 1

Chronic lymphatic leukemia . . . . . . 9

Hemolytic anemia . . . . . . . . . . 2

Stem cell leukemia . . . . . . . . . . 8

Lymphosarcoma . . . . . . . . . . . 3

Reticulum cell sarcoma . . . . . . . . 1

Acute lymphocytic leukemia . . . . . . 1

Multiple myeloma . . . . . . . . . . 3

Chronic peritonitis . . . . . . . . . . 1

Chronic sinusitis . . . . . . . . . . . 1

Tuberculosis . . . . . . . . . . . . 2

Congenital aplastic anemia . . . . . 2

Eczema . . . . . . . . . . . . . . 2

Hypoglycemia . . . . . . . . . . . . 1

Vitamin D intoxification . . . . . . . 1

Letter-Siwe . . . . . . . . . . . . . 1

Neuroblastoma . . . . . . . . . . . 1

Monocytic leukemia . . . . . . . . . 1

Acute myelogenous leukemia . . . . . 1

Chronic myelogenous leukemia. . . . . 3

Waldenstrom's macroglobulinemia . . . 1

Adreno-genital syndrome . . . . . . . 1

Follicular lymphoma . . . . . . . . . 1

Thrombocytopenia . . . . . . . . . . 1

Cytomegalic inclusion disease . . . . . 1

Immunosuppressive agent

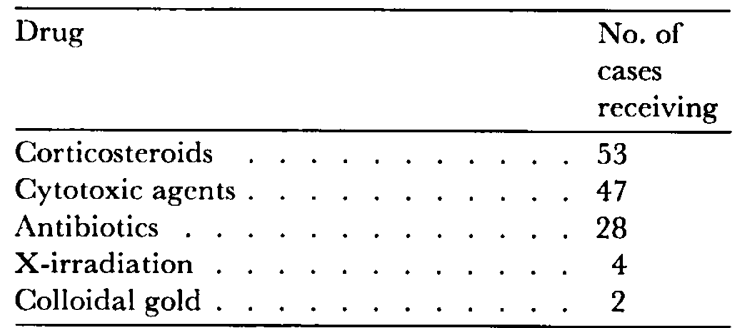


Table VIII. Incidence of Pneumocystis carinii pneumonitis in patients with lymphoreticular malignancies

\begin{tabular}{llll}
\hline $\begin{array}{l}\text { Total } \\
\text { autopsies }\end{array}$ & $\begin{array}{l}\text { No. of } \\
\text { cases }\end{array}$ & Type of malignancy & No. \\
\hline 323 & 12 & $\begin{array}{l}\text { Stem cell leukemia } \\
\text { Hodgkin's disease }\end{array}$ & 6 \\
& & $\begin{array}{l}\text { lymphosarcoma } \\
\text { reticulum cell sarcoma }\end{array}$ & 2 \\
& & chronic lymphatic leukemia & 1 \\
\hline
\end{tabular}

After: Esterly, J.A. et al.: Arch.Path. 80: 433 (1965) (169)

tion of patients receiving renal allografts and receiving concomitant immunosuppressive therapy reveal that Pneumocystis infection comprises a significant cause of morbitity and mortality (table IX) $[39,89]$. Associated with Pneumocystis infection, as in the newborn and premature group, is cytomegalic inclusion disease. In such cases, it has been possible to recover Pneumocystis cysts in a significant fraction of sputum samples of affected patients [89].

Since a chemotherapeutic approach to this disease has been shown to be successful in a patient with lymphoreticular malignancy receiving cytotoxic agents, diagnostic measures to demonstrate the lesion should made [171] (see case 3 ).

Of interest is the association of gold therapy and Pneumocystis infection [145]. Recently, it has been reported that colloidal gold given for rheumatoid arthritis may result in a deficiency of serum immunoglobulin formation [169]. It is probable that any drug with a depressant effect upon immunological function may incite latent infections. This relationship should be sought in the investigation of interstitial pneumonitis of obscure origin in patients receiving any chemotherapy known to have a depressant action upon host resistance.

\section{Clinical and Laboratory Findings}

As discussed in the previous section, the direct demonstration of Pneumorystis cysts in the sputum is quite difficult. Obtaining a positive analysis of Pneumocystis in sputum is more infrequent in the younger age group, perhaps, reflecting the inability to obtain a proper specimen. Analysis of all the case material used in this text indicates that the most consistant pathophysiologic state demonstrable in Pneumocystis carinii pneumonitis is the abnormal pulmonary respiratory physiology. The alteration in the pulmonary respiration is most effectively described as being consistent with 'an alveolar-capillary block' syndrome.
Thorough analysis of the respiratory deficiency in Pneumocystis carinii pneumonitis is not available. A unique case, well studied, has been reported and the data is summarized in table $\mathbf{X}[60]$. The subject was an adult male without a history of having received immunosuppressive or antimicrobial chemotherapy. Analysis of many tissues at the autopsy did not reveal other pathological processes. At the time of the physiologic studies, the $x$-rays showed a diffuse bilateral inflammation characteristic of the interstitial pneumonitis seen in Pneumocystis infection. The altered physiology is consistent with the syndrome called 'alveolarcapillary block'. In this condition, the lungs are stiff and noncompliant, but there is relatively little obstruction to the flow of air through the major airways. The result of this altered physiology is that there is relatively little impairment of the excretion of the relatively soluble carbon dioxide which diffuses across the alveolar septa. In contrast, oxygen is only slightly soluble in the pulmonary solvents and is poorly transported across the inflamed and thickened alveolar septa. Increasing the oxygen tension of the inspired air increases the oxygenation of pulmonary capillary blood because there is relatively little obstructive element in this disease. Since there is no obstruction to the movement of gases in the large airways, there is relatively unimpaired excretion of most of the venous carbon dioxide. Thus, there is effective regulation of normal serum $\mathrm{pH}$ until late in the course of the disease. Increasing the oxygen content of the inspired air has a marked clinical effect as evidenced by a lessening of the cyanosis. Part of the dissociation of the clinical symptoms (cyanosis and tachypnea) from the severe pulmonary findings exhibited by these patients may be due to the relatively unimpaired pulmonary regulation of the serum $\mathrm{pH}$.

Similar but incomplete pulmonary function studies of infants with Pneumocystis carinii pneumonitis has been documented (table XI) [176]. A survey of the serum sodium, pH, and chloride levels induced by Pneumocystis disease with severe hypoxemia have shown the relatively normal $\mathrm{PCO}_{2}$ and $\mathrm{pH}$ in the presence of cyanosis and severe arterial oxygen desaturation [177, 178]. Further analysis of serum chloride levels and $\mathrm{pH}$ as well as $\mathrm{PCO}_{2}$ in various reports, which have been used as a crude analysis of serum acid base regulation, are consistent with the hypothesis that the distorted pulmonary function induced by Pneumocystis is an alveolar-capillary block and is present in individuals of all age groups $[69,75,89,97,111,121,140]$. This correlates well with the primary pathologic lesion, that of a thickened and scarred alveolar septa, characteristic of Pneumocystis carinii pneumonitis. Other diseases that have alveolar-capillary block also have a similar pathological lesion. 
Table IX. The significance of Pneumocystis carinii infection as a cause of mortality and morbidity in patients receiving immunosuppressive chemotherapy following renal transplants is shown.

Infectious pulmonary disease in patients recciving immunosuppressive therapy for kidney transplantation

\begin{tabular}{llc}
\hline Transplant & Etiologic agent & $\begin{array}{l}\text { No. of } \\
\text { cases }\end{array}$ \\
\hline Kidney & cytomegalovirus & 14 \\
& pscudomonas aeruginosa & 8 \\
& candida albicans & 7 \\
& Pneumocystis carinii & 3 \\
staphylococcus aureus & 3 \\
aspergillus & 2 \\
diplococcus pneumoniae & 1 \\
& norcardia asteroides & 1 \\
& E. coli & 1 \\
M. tubcrculosis & 1 \\
Total & 41 \\
\hline
\end{tabular}

After: Hil.L, R. B. : New Engl.J. Med. 271: 1021 (1964)
Table $X$. Analysis of the altered pulmonary physiology in an adult patient with Pneumocystis carinii verified at post mortem examination is summarized. The extreme degree of hypoxemia with relatively normal $\mathrm{pCO}_{2}$ and $\mathrm{pH}$ is characteristic of impaired diffusion of inspired air across alveolar septal membranes (alveolar-capillary block).

Pulmonary function studies of an adult male with advanced Pneumocystis carinii pneumonitis

1. Pulmonary compliance $0.02 \mathrm{l} / \mathrm{cm} \mathrm{H}_{2} \mathrm{O}$ (normal $0.02 \mathrm{l} / \mathrm{cm} \mathrm{H}_{2} \mathrm{O}$ )

2. Nonelastic resistance $2.63 \mathrm{l} / \mathrm{cm} \mathrm{H}_{2} \mathrm{O} /$ second (this is normal value)

3. Tidal volume $435 \mathrm{ml}$ (BTPS)

4. Respiratory rate 42 /minute

5. Arterial $\mathrm{O}_{2}$ saturation $57.5 \%$ (measured during IPP with $40 \% \mathrm{O}_{2}$ in inspired air)

6. Arterial $\mathrm{CO}_{2}$ tension $26 \mathrm{~mm} \mathrm{Hg}$ (normal $40 \mathrm{~mm}$ $\mathrm{Hg})$

7. Arterial pH 7.59 (normal 7.40)

After: Lyons et ai.: Arch.intern. Med. 108: 173 (196I)

Table XI. Metabolic studies, conducted on normal newborns and infants with respiratory disease confirm the findings of alveolar-capillary block syndrome. Patients with Pneumocystis carinii pneumonitis exhibit low arterial oxygen saturation with relatively normal plasma $\mathrm{pH}$ values.

\begin{tabular}{|c|c|c|c|c|}
\hline \multicolumn{5}{|c|}{ Metabolic studies of infants with Pneumocystis carinii pneumonitis } \\
\hline Diagnosis & $\begin{array}{l}\text { No. of } \\
\text { cases }\end{array}$ & $\begin{array}{l}\mathrm{pCO}_{2} \\
(\mathrm{~mm} \mathrm{Hg})\end{array}$ & $\begin{array}{l}\text { Plasma } \\
\mathrm{pH}\end{array}$ & $\begin{array}{l}\text { Arterial } \\
\mathrm{O}_{2} \text { Sat. } \\
{ }^{\prime}\end{array}$ \\
\hline 3-month malnourished prematures & . 6 & $\begin{array}{l}37.5 \\
+01\end{array}$ & $\begin{array}{l}7.4 \\
+0.02\end{array}$ & 95 \\
\hline Normal prematures. . . . . . . . & . 12 & $\begin{array}{l} \pm 5 \\
\pm 2.55\end{array}$ & $\begin{array}{l} \pm 0.02 \\
7.25 \\
\pm 0.09\end{array}$ & $\begin{array}{l}89 \\
\pm 8.84\end{array}$ \\
\hline Anoxia newborn prematures . . . & . 16 & $\begin{array}{l}75.1 \\
(46-100)\end{array}$ & $\begin{array}{l}6.82 \\
(6.45-7.25)\end{array}$ & - \\
\hline Pneumocystis carinii . . . . . . . . & . 7 & $\begin{array}{l}55.2 \\
(27-80)\end{array}$ & $\begin{array}{l}7.25 \\
(7.10-7.40)\end{array}$ & $\begin{array}{l}29.5 \\
(20.0-42.0)\end{array}$ \\
\hline
\end{tabular}

After: Kerpel-Fronius, E. et al.: Arch. Dis. Childh. 39: 473 (1964)

The complication reported by LEBEDA [73] is probably related to the marked increase in 'work' of respiration, characteristic of the syndrome. 'Spontaneous' rib fractures may occur more frequently than this single report would indicate. Pain from such a fracture could conceivably further compromise the depressed respiration and should be considered as a complication to be watched for in infants.
Analysis of all cases, divided into newborn and premature groups, and those individuals with primary or secondary immunological deficiencies, has not revealcd any consistent pattern of change of the peripheral leukocyte count or distribution of cell types that would aid in the diagnosis of Pneumocystis infection. Fever is irregularly present. Immunoglobulin determinations, absolute lymphocyte count, and immuno- 
logical reactivity towards antigens that are tested by serum antibody or delayed-type hypersensitivity are helpful in defining an immunological deficiency. However, the disease has been reported in all types of immunological deficiencies described to date. Thus, there is no good clue about immunity to Pneumocystis carinii that can be extracted from these cases since both depression of serum antibody biosynthesis and 'cellular' immunity may predispose the host to Pneumocystis carinii pneumonitis. Apparent eradication of the parasite by chemotherapy with pentamidine isothionate in one patient has been followed by a recrudescence of infection with Pneumocystis [142]. A similiar finding has been reported in experimental animals [54].

\section{Animal Model}

Pneumocystis infection can be induced in a variety of experimental animals, as well as occurring as a socalled 'natural' infection (tables II and XII) [7, 9-14, $42,54,55,179]$. Induction of the infection in normal animals in various experimental models has proven to be a valuable adjunct to clinical and pathological data in humans because it has provided a greater understanding of the pathogenesis of the disease as well as the useful experimental tool to study the effects of chemotherapeutic agents. In brief, the experimental results may be summarized as follows. Pneumocystis infection can be induced in animals with a variety of chemotherapeutic agents without specific exposure to a known source of Pneumocystis carinii. Prolonged treatment of normal animals with immunosuppressive drugs such as corticosteroids alone, or in conjunction with antimicrobial agents, is sufficient to result in Pneumocystis carinii pneumonitis. Two agents with different inhibitory activities towards host defense mechanisms will induce a significant infection in most animals. Nonfatal infection as evidenced by the demonstration of recovery and/or the presence of cysts without severe pneumonitis in a significant proportion of animals may follow the use of one agent alone [11, 56]. Suckling, newborn, and adult animals are susceptible to the induced induction of Pneumocystis infection by these agents. The relative ease with which the disease can be induced in the rat is shown in table XIII. Specie differences as well as different experimental designs used to study Pneumocystis carinii infection are shown in table XIV.

The pathologic lesion induced by such manipulation has been shown to parallel very closely those seen in humans. Illustrations (figs. 7A and B), kindly supplied by Dr. Walter Sheldon at the Johns Hopkins University, shows that thickened interstitial septa and intra alveolar exudate characteristic of the morphological lesion seen in humans [11]. A careful search of experimental animals has failed to demonstrate cysts at any other site other than the pulmonary parenchyma. Thus, the nature of the induction in the pathologic process and the response to chemotherapeutic agents parallel these features observed in humans. Both animal and human data are consistent with the concept that Pneumocystis carinii pneumonitis is a disease caused by an ubiquitous organism of low virulence and narrow tissue specificity in a susceptible host.

Of interest is the inability to show serological reactivity with cysts extracted from animal lungs as compared to those extracted from human material [42]. One of the limitations of the serological test, however, is the nature of the antigenic material. The antigenic material is a crude extract taken from whole tissue. Cross species reactions with pulmonary tissue must be removed by absorption of either species serum with the heterologous lung tissue. Such absorption procedures result in a loss of activity of one species antibody to the antigen extracted from the other species lung. It is entirely possible that the extensive absorption procedure itself may destroy the effectiveness of the test. It cannot be stressed too strongly that a source of pure antigen is needed to understand whether there is a species specificity in Pneumocystis carinii. The importance of this observation is critical in an analysis of sources of organism in nature. If species specificity does exist, then a search for this organism in the experimental models already studied indicates that these animals do not constitute a significant reservoir of infection for humans.

Thus, in the experimental model, Pneumocystis carinii can be shown to be a latent infection. The cysts are present in experimental animals in too few number to be demonstrated by ordinary techniques. Suppression of the normal host's resistance by corticosteroids, antimetabolites, or antimicrobial chemotherapeutic agents activates a Peeumocystis infection. The lesion is confined to the pulmonary parenchyma and the pathologic process is very similar to that seen in humans.

\section{Chemotherapy}

Many attempts, using chemotherapeutic agents, have been made to treat Pneumocystis carinii pneumonitis $[46-53,92,123,124,130,142,149,171,180-183]$. The most successful among these has been the introduction of pentamidine isothionate by IVADY $[46,47]$. Since introduction of the anti-trypanosome drug, many other investigators have reported its usefulness both in human and experimental animals [54]. One of the considerations in evaluating such an experimen- 
Table XII. The experimental manipulations necessary to induce Pneumocystis carinii pneumonitis in the rabbit are summarized. Note that human cysts, taken at autopsy do not serve as a good source of infecting material. Antimicrobials plus cortisone are sufficient to induce a Pneumocystis infection without direct exposure of the animals to the cysts.

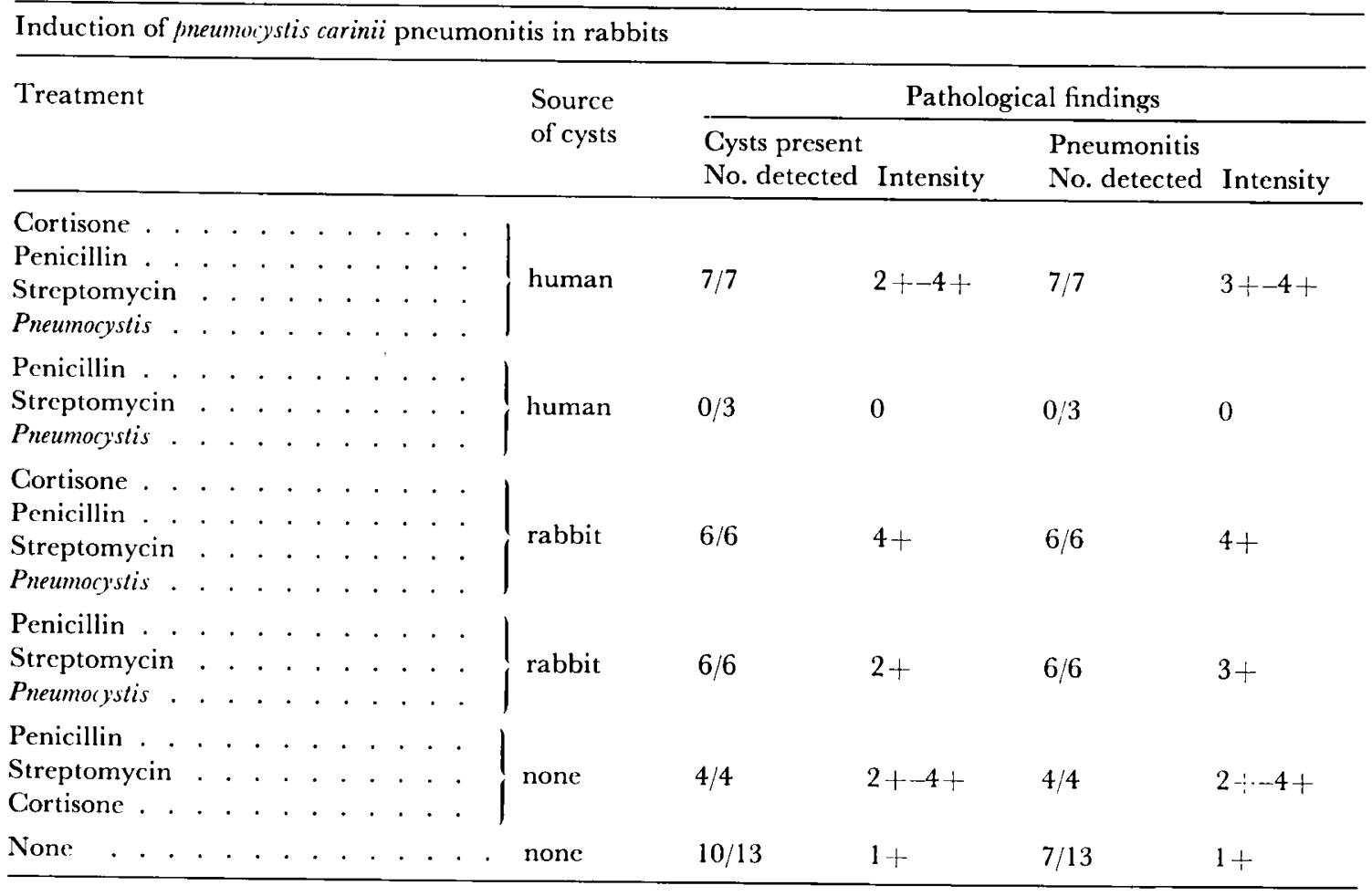

After: Sheldon, W.: J.cxp. Med. 110: 147 (1959)

Table XIII. The relative ease with which Pneumocystis curinii pneumonitis can be induced without an exogenous source of infectious material is shown.

Frequency of Pneumocystis carinii pncumonitis in normal adult rats treated with cortisone $(4.0 \mathrm{mg} / 100 \mathrm{gm}$ body weight for 40 days)

\begin{tabular}{|c|c|c|}
\hline Treatment & $\begin{array}{l}\text { No. of } \\
\text { animals }\end{array}$ & $\begin{array}{l}\text { No. with } \\
\text { Pneumocystis carinii } \\
\text { infection }\end{array}$ \\
\hline 1. Cortisone & 40 & 28 \\
\hline $\begin{array}{l}\text { + Pneumocystis }\end{array}$ & 54 & 33 \\
\hline $\begin{array}{l}\text { 3. Pneumocystis } \\
\text { 4. None }\end{array}$ & 14 & 33 \\
\hline
\end{tabular}

After: Weller, R.: Z. Kinderheilk. 78: 166 (1956) (56)
Table XIV. Experimental manipulations used to induce Pneumocystis carinii pneumonitis in experimental animals

\begin{tabular}{|c|c|c|}
\hline Species & Manipulation & Reference \\
\hline Rats & cortisone & $\begin{array}{l}\text { Ricken, D.: Virchows } \\
\text { Arch.path. Anat. } 331 \text { : } \\
713 \text { (1958) }\end{array}$ \\
\hline Rabbits & $\begin{array}{l}\text { antibiotics and } \\
\text { cortisone }\end{array}$ & $\begin{array}{l}\text { Sheldon, J.: Exp. Med. } \\
110: 147(1959)\end{array}$ \\
\hline Mice & $\begin{array}{l}\text { cortisone and } \\
\text { cysts }\end{array}$ & $\begin{array}{l}\text { BAstamante } \text { et al.: } \\
\text { Mschr. Kinderheilk. } \\
\text { 103: } 145(1960)\end{array}$ \\
\hline Rats & $\begin{array}{l}\text { cortisone, cyclo- } \\
\text { phosphamide, } \\
\text { cortisone and } \\
\text { antimetabolites } \\
\text { X-ray irradiatio }\end{array}$ & $\begin{array}{l}\text { Frenkel, J. et al.: } \\
\text { Lab. Invest. 15: } 1559 \\
(1966)\end{array}$ \\
\hline
\end{tabular}




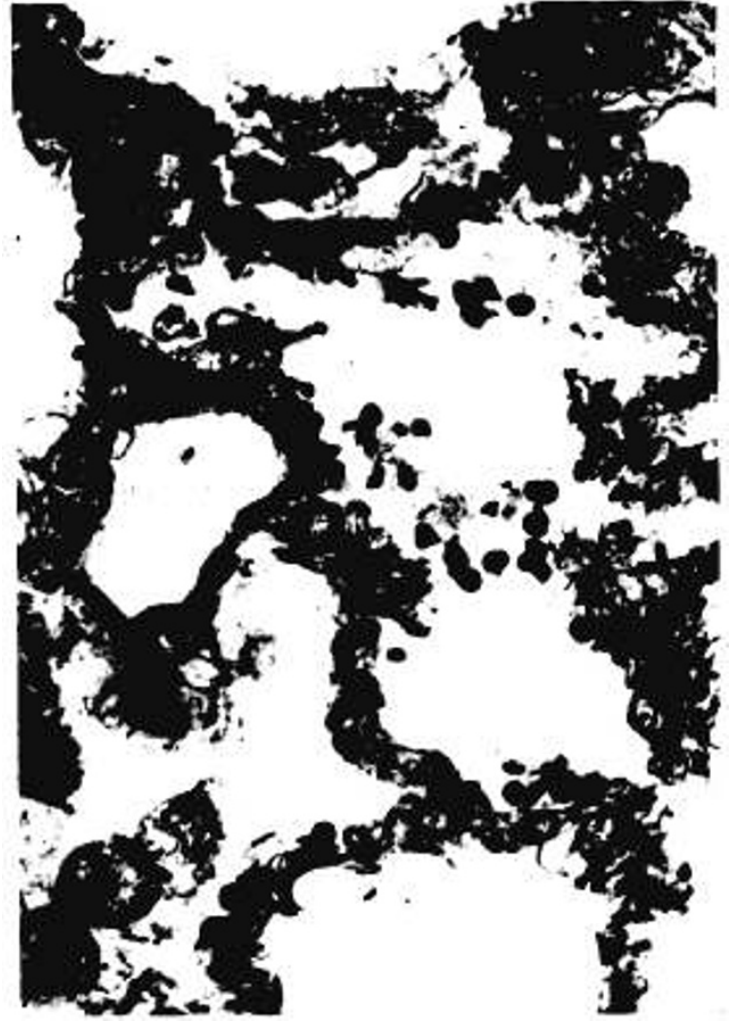

Fig. 7 and $B$. This photomicrograph, kindly made available to us through the courtesy of Dr. Walter Sheldon, Department of Pathology, Johns Hopkins University College of Medicine, shows the morphological lesion of induced Pneumncystis carinii in the rabbit. The fibrosis of the alveolar interstitial tissue, the intraalveolar exudate and the relatively clear bronchioles closely mimick the pathological process observed in the human.

Table XV. The effectiveness of anti-Pneumocystis chemotherapy with pentamidine isothionate over a four-year period is shown. The dramatic fall in the percent of fatalities in affected prematures is consistant with the few successfully treated cases in adults reported to date. Effectiveness of pentamidine isothionate in treatment of Pneumocystis carinii pneumonitis in prematures

\begin{tabular}{llccc}
\hline Treatment & Year & $\begin{array}{l}\text { No. of } \\
\text { cases }\end{array}$ & $\begin{array}{l}\text { No. of } \\
\text { deaths }\end{array}$ & $\begin{array}{l}\text { Fatalities } \\
(\%)\end{array}$ \\
\hline None & 1960 & 9 & 6 & 66 \\
Pentamidine & $1961-64$ & 44 & 4 & 9 \\
\hline
\end{tabular}

After: LoRINCZI, K. et al.: Gyermekgyogyaszat 15: 270 (1964)

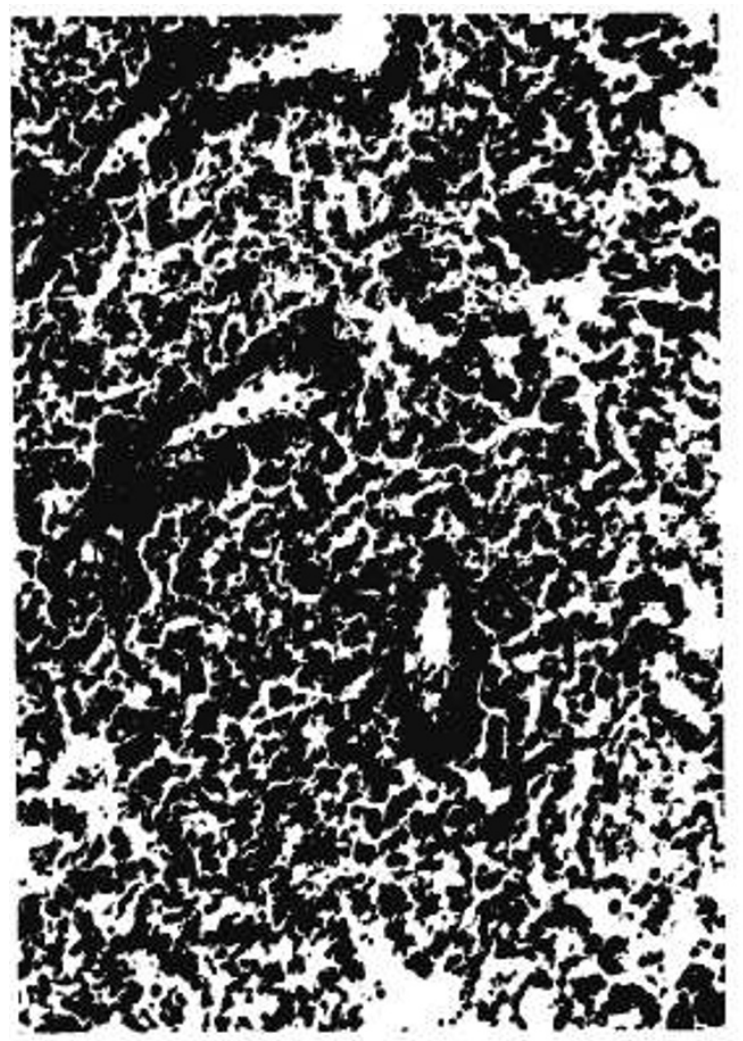

tal drug is the accurate determination of the clinical course in this disease. This has been a difficult task. The two reports listed $[103,184]$ would indicate that in some hands, recovery from the disease is a usual outcome; whereas, in others, the disease seems to be almost universally fatal. The difficulty in assessing the outcome of a Pneumocystis carinii infection is compounded by the nature of the previous dispossessing disease and the difficulty in truly cstablishing whether or not the pneumonitis has resulted from a Pneumocystis infection.

It can be seen from the illustrative case material at the beginning of this report that many diseases have the typical clinical and x-ray appearance of Pneumocystis infection. Accurate diagnosis of this disease has been difficult because of the inability to positively identify the organism outside of lung tissue. Thus, evaluation of the effectiveness of drug therapy has been difficult. Nevertheless, in instances where the diagnosis has been accurately established by pathologic material or demonstration of the cysts in the sputum, treatment of the individual with the drug has proven to be an effective therapeutic regime. A summary of a long experience with the drug, pentamidine isothionate (table XV), shows that the use of this drug would seem to be an effective therapeutic tool. 
The drug, now available in the United States ${ }^{1}$, has been shown to be an effective agent for the prophylactic treatment of African trypanosomasis [185]. A toxic side effect noted in a case studied by the author [51] and later substantiated in humans and animals has becn the appearance of an increase in megaloblasts in the bone marrow. These changes are consistent with a folic acid deficiency. Analysis of the serum of folic acid in our patient receiving this drug showed a normal level without displacement of the bound folic acid. Therefore, our tentative conclusion is that pentamidine isothionate acts as a direct inhibitor of folic acid similar to that induced by aminopterin. In animal work, Frankel reported that pretreatment with folinic acid did not disturb the therapeutic effectiveness of pentamidine although it did prevent the megaloblastosis in the rat [54]. While it is still too early to conclude that folic acid is a useful adjunct to therapy with pentamidine, it would scem that this might be a beneficial procedure. The uscfulness of the folic acid or its derivatives for treatment is based upon the observation that folic acid cannot be directly utilized by microorganisms; therefore, the interference with folic acid presumably induced by pentamidine would scem to be an intraparasitic metabolic block. This assumption has not been directly shown for Pneumocystis carinii. The alteration in the bone marrow was readily reversible after cessation of the therapy. Therefore, these factors should be considered when approaching the problem of the toxicity of pentamidine.

Directly involved in consideration of the effectiveness of a therapeutic regime is the long term effect of the infection upon the host. Unfortunately, little data is available to answer this question. In our case [51] (see case report) two factors should be emphasized. The first is the persistence of confirmed sinopulmonary disease in this patient despite replacement therapy with commercial immunoglobulin. Therapy was gauged by analysis of serum IgG levels prior to monthly injection of gamma globulin. An attempt was made to maintain a serum level of at least $300 \mathrm{mg} \%$ prior to reinjection. This inability to control the persistent respiratory tract infections, reported by many others, has prompted the frequent use of various antimicrobial agents. To date, there has been no reactivation of Pneumocystis carinii infection during the three years following therapy in this patient despite the continued chemotherapy. There is some indication that other drug regimes may be useful [54, 89]. Anti-protozoan agents, in general, have been studied. The therapeutic regime of pyramethaminc and sulfonamides, successful in the treatment of toxoplasmosis, seems to have a beneficial effect in experimental Pneumocystis infection. How-

1 Rhodia Inc., 600 Madison Avenue, New York, N.Y. ever, the high risk of thrombocytopenia due to the pyramethamine would seem to make pentamidine the current drug of choice.

\section{Ciourse and Prognosis}

An analysis of the natural course of Pneumocystis carinii infection is hindered by several factors. The first, previously mentioned, is the difficulty in arriving at precise diagnosis of this disease. Direct demonstration of Pncumocystis cysts in sputum of affected patients is infrequent and obtaining tissue samples in a sick individual presents a problem with a calculated risk. There is no information which correlates the severity of clinical symptoms and the frequency of positive identification of the cysts.

The second problem confronting the investigator is the similarity between the symptoms and signs of Pneumocystis carinii pneumonitis and other diseases characterized by pulmonary interstitial fibrosis [81, $85,88,99,185$, case 5]. Case number five, diagnosed as interstitial pneumonitis of infancy, was clinically indistinguishable from Pneumocystis carinii pneumonitis. Without adequate morphological evidence, a spontaneous 'cause' would have been assumed in this instance. Such discase entities may, in part, explain the divergent clinical findings of recovery from Pneumocystis disease [102, 184].

The third problem is to decide if, in fact, recovery from the Pneumocystis infection has occurred in the presence of another disease. This is a particularly critical problem in the adult age group. Case 2 (D.H.) would suggest that clinical cure can indeed be effected, as evidenced by a return of pulmonary function without limitation of activity. In the case reported by WANTABE [120], a normal teenage child and her mother presumably contracted the discase from an infected father. The child and the mother developed clinical signs and symptoms strongly suggestive of Pneumocystis disease within several months of each other. The child recovered without specific therapy or direct morphological diagnosis. Autopsy material obtained from the mother, who expired from a pneumonitis similiar to that of the child and the father, confirmed the diagnosis of Pneumocystis infection. One would have to assume that both individuals contracted the same disease and that recovery without specific chemotherapy can occur. 'Spontancous' recovery in an individual with an identifiable predisposing disease has not been reported.

Our conclusion from these data is that'spontaneous' recovery from Pneumocystis carinii pneumonitis has occurred. With severe clinical symptoms, untreated individuals usually succumb to the disease. Similarly, patients with a significant predisposing disease would 
scem to have a highly predictable fatal prognosis without chemotherapy.

Another important aspect of the problem of analyzing the prognosis of affected individuals is the lack of information regarding the injured pulmonary parenchyma. Information regarding long term followthrough of patients who have recovered from Pneumocystis carinii pncumonitis is not available. Case number one, an example of acquired hypogammaglobulinemia as predisposing cause, has been studied for three years following the initial infection. During this time, despite repeated episodes of otitis media and pneumonia treated with antibiotics, no cvidence of reactivation of Pneumocystis infection has occurred. The patient has undergone carly sexual maturation, particpaties in all activities in school and plays without restriction. However, a significant diminution in pulmonary function still persists as evidenced by a lowered vital capacity and diffusion gradient. The diminution in these functions has remained unchanged through the three years of study. Although the restriction in vital capacity may be attributed to the injury induced by her immunological deficiency and resultant bacterial infections, the diminished alveolar function is best explained as a consequence of her Pneumocystis infection. It may be inferred that early diagnosis and treatment of this disease may result in less permanent pulmonary injury.

Interference with bone marrow metabolism, as evidenced by the megaloblastosis observed in several individuals has not persisted following cessation of therapy.

Following institution of chemotherapy with pentamidine, the progressive character of the disease ceases within one weck $[46-53,171,172]$. Fever, tachypnea, and cyanosis decrease in intensity and a sense of improvement is reported by the patient. Roentgenographic improvement may not be evident for two to three weeks. Intramuscular administration of $4.0 \mathrm{mg} / \mathrm{kg}$ intramuscularly for fourteen days has seemed to be an effective schedule.

\section{Summary}

Pneumocystis carinii pneumonitis is best described as an example of an infection with an organism of low virulence. It is an ubiquitous parasite of undetermined classification because of the difficulty in examining the morphology and physiology of the organism. The emergence of the organism in significant numbers in the lung parenchyma under unusual conditions would classify it best as an example of a latent infection in a predisposed host. The agents or pathological processes which predispose the animal and human host have been described. A careful analysis of these cases and data obtained from animal models have suggested that the differences in the disease thought to be due to age and developmental status of the host are not as great as one had presumed. Similar pathogenetic and pathological mechanisms are found in both the ncwborn and adult group. Chemotherapeutic agents play an important role in altering the normal physiology of the hosts of all age groups in normal and in diseased individuals.

The narrow range of tissue specifirity and the unusual metabolic alterations induced by infection with this organism have been emphasized. An attempt was made to correlate the morphological lesion with clinical observation and laboratory data. A successful chemotherapeutic agent is now available for the treatment of this discase. Since the few cases which have been studied have revealed a permanent disability due to the alveolar scpta fibrosis, and since a successful chemotherapeutic agent is available, prompt diagnosis and treatment have been advocated. The wide variety of disease states that may predispose to Pneumocystis carinii pneumonia has been emphasized. It is hoped that future work, which may permit more careful biochemical, genetic and morphological analysis of the organism, will allow precise identification of Pneumocystis carinii outside of the diseased host and the distribution of the parasite in the environment.

$\mathrm{X}$-ray films have returned to normal in about two to three months following therapy in the case studied at our institution.

\section{References and Notes}

1. Carini, A. und Maciel, J.: Über Pneumocystis carinii. Zbl. Bakt. 1: 46 (1915).

2. Jirovec, O.: Pneumocystis carinii, pulvodect, zv. interstitialnich plasmocelularnich pneumonii kojencu. Čs. Hyg. Epid. Mikrob. 1: 141 (1952).

3. Gerrard, J.W.: Pneumocystis pneumonia. Symposium on recent clinical advances, May 1958. Pediat. Clin. N. Amer. pp. 327-335 (Saunders, Philadelphia/London 1958).

4. Goetz, O.: Klinik und Pathologie der interstitiellen plasmazellulären Pneumonie. Archiv Kinderheilk. 41: 1-73 (1960).

5. Gajpusek, D.C.: Pneumocystis carinii ; etiologic agent of interstitial plasma cell pneumonia of premature and young infants. Pediatrics 19: 543-565 (1957).

6. Falkenbach, K.H.; Bachmann, K.D. and O'Loughlin, B.J.: Pneumocystis carinii pneumonia. Amer. J. Roentgenol. 85: 706-713 (1961).

7. Porter, A.: The occurrence of Pneumocystis carinii in mice in England. Parasitology 8: 225 (1915). 
8. VANek, J.; Jirovec, O. and Lukes, J.: Interstitial plasma cell pneumonia in infants. Ann. paediat. Basel 180: 1-21 (1953).

9. Brandstein, L. and Csillag, A.: Experimental interstitial plasma cell pneumonia in sucking mice. Orv. Hetil. 95: 1003-1006 (1954).

10. Goetz, O. : Experimental contributions to the etiology of interstitial plasma cell pneumonia. Münch. med. Wschr. 101: 1411-1413 (1959).

11. Sheldon, W.H.: Experimental pulmonary Pneumocystis carinii infection in rabbits. J.exp. Med. 110: 147-160 (1959).

12. Аккеr, S. and Goekbloed, E.: Pncumonia caused by Pneumocystis carinii in a dog. Trop. geogr. Med. 12: $54-58$ (1960).

13. Jirovec, O.: Toxoplasmosis and Pneumocystosis as anthrapozoonoses. Zh. Mikrobiol. 32: 1890-1898 (1961).

14. Fuchs, U. Submicroscopic changes of the rat lung following the administration of a coumartin derivative. Frankfurt. Z. Path. 74: 555-564 (1965).

15. Bustamante, W.; Moreno, L. and Diaz, M.: Interstitial plasma cell pneumonias with demonstration of Pneumocystis carinii in Chile. Mschr. Kinderheilk. 108: 145-146 (1960).

16. BRITo, T. DE and ENGE, L.G.: Interstitial plasma cell pneumonia caused by Pneumocystis carinii. Rev. Inst. Med. trop. S. Paulo 4: 261-268 (1962).

17. Ryan, B.: Pneumocystis carinii infection in Melanesian children. J. Pediat. 60: 914-916 (1962).

18. Thys, A. and Janssens, P.G.: Pneumocystosis in Congolese infants. Trop.geogr. Med. 15: 158-172 (1963).

19. Trys, A.: Pneumocystosis in Congolese infants. Verh. vlaam. Akad. Geneesk. Belg. 25: 285-314 (1963).

20. Post, C.; Dutz, W. and Nasarian, I.: Endemic Pncumocystis carinii pneumonia in South Iran. Arch. Dis. Childh. 39: 35-40 (1964).

21. Jirovec, O.: Interstitial pneumonia in infants caused by Pneumocystis carinii. Mschr. Kinderheilk. 102: 476-485 (1954).

22. Reisetbauer, E. and Moritsch, H.: Epidemiological and serological studies on interstitial plasma cell pneumonia in prematures. Mschr. Kinderheilk. 104: $41-46$ (1956).

23. Jirovec, O.: The problem of Pneumocystis pneumonia from the parasitological point of view. Mschr. Kinderheilk. 108: 136-142 (1960).

24. Paschlau, G.: Epidemiological observations with the aid of the complement fixation reaction toward the pathogen of interstitial pneumonia. Mschr. Kinderheilk. 108: 151-152 (1960).

25. Giese, H.: Etiology of the interstitial plasmacellu- lar infant pneumonia. Mschr. Kinderheilk. 101: 147-149 (1953).

26. Bieling, W.: Protozoan infections. Dtsch.med. Wschr. 78: 1801-1802 (1953).

27. Bauch, R. and Ladstater, L.: Pneumocystis carinii and interstitial plasma cell pneumonia in premature infants. Klin. Wschr. 31: 37-38, 900902 (1953).

28. Sснмid, K. O.: Etiology of interstitial plasmocellular pneumonia (saccharomycosis) in infants; identification of Pneumocystis carinii with Saccharomyces fragilis. Frankfurt.Z.Path. 66: 426448 (1955).

29. Steiner, B.; Szabon, J. and Mohacsi, A. : Diagnostic value of fungus studies in interstitial plasma cell pneumonia. Helv.paediat. Acta 11:501-505 (1956).

30. HAmperL, H.: The pathological anatomy of interstitial pneumonia. Mschr. Kinderheilk. 108: 132 (1960).

31. Nitschke, A. and Heyn, K.: On the problem of the histological demonstration of Pneumocystis in interstitial pneumonia. Mschr. Kinderheilk. 108: 142-144 (1960).

32. Gadeke, R.: Morphological antigen-antibody localization with fluorescent antibodies in lung tissue in interstitial pneumonia. Mschr. Kinderheilk. 108: 152-156 (1960).

33. Scrmid, K. O.: Studies on Pneumocystis disease in man. II. Developing Pneumocystis pneumonia in chronic lymphadenosis of an adult. Frankfurt. Z. Path. 74: 146-161 (1964).

34. Zandanell, E.: Finding of Pneumocystis outside of the lungs in interstitial plasma cell pneumonia in infants and in premature. Zbl.allg. Path., path. Anat. 92: 75-80 (1954).

35. Willmer, E. N.: Cells and tissues in culture; methods, biology and physiology (Academic Press, New York/London 1965).

36. Navratil, B.; Smid, Z. and Barta, K. : Serological determination of interstitial pneumocystic pneumonia in infants. Ann. paediat. (Basel) 183: 59-64 (1954).

37. Vivel , O.: A new serodiagnostic method in interstitial plasma cell pneumonia in newborn and premature infants. Dtsch.med. Wschr. 79: 358-360 (1954).

38. Vivell, O.; Buhn, W.H. and Lips, G.: Experiences with serodiagnosis of interstitial plasma cell pneumonia of young and premature infants. $\mathrm{Z}$. Kinderheilk. 78: 653-666 (1956).

39. Jahn, E. and Roller-Gusinde, R.E.: Serology and clinical aspects of interstitial plasma cell pneumonia. Klin. Wschr. 35: 37-41 (1957).

40. Goetz, O.: The antigen of interstitial pneumonia. Klin. Wschr. 36: 118-120 (1958). 
41. ViVELL, O.: The serology of interstitial pneumonia. Mschr. Kinderheilk. 108: 146-151 (1960).

42. BARtA, K. and Lysek, H. : Experimental pneumocytosis. I. Studies on complement fixation antibodies. Cs. Epidem. 11: 196-202 (1962).

43. Goetz, O. : Serological findings in interstitial pneumonia from the U.S. Arch. Kinderheilk. 170: 60-66 (1964).

44. Goetz, O.: Fluorescence microscopic studies in interstitial plasma cell pneumonia. Mschr. Kinderheilk. 113: 194-197 (1965).

45. BARTA, K.: On the problem of the antigen effective components of the lung in pneumocystic pneumonia. Path. et Microbiol. Basel 29: 63-74 (1966).

46. Ivady, G. and PALDy, L. : New method of treating interstitial plasma cell pneumonia in premature infants with 5-valent antimony and aromatic diamidines. Mschr. Kinderheilk. 106: 10-14 (1958).

47. Ivady, G.; PAldy, L. and UnGer, G.: Further experiences in the treatment of interstitial plasma cell pneumonia with pentamidine. Mschr.Kinderheilk. 111: 297-299 (1963).

48. Rodger, T.S. and Haggie, M.H.K.: Pneumocystis carinii pneumonia associated with hypogammaglobulinemia responding to pentamidine. Lancet $i$ : 1042 (1964).

49. Lorinczi, K.: Our experiences with pentamidine in the treatment of interstitial plasma cell pneumonia. Gyermekgyógyászat 15: 207-212 (1964).

50. Marshall, W. C. ; Weston, H.J. and Bodian, M. : Pneumocystis carinii pneumonia and congenital hypogammaglobulinemia. Arch. Dis. Childh. 39: 18-25 (1964).

51. Robbins, J. B.; Miller, R.H.; Arean, V.M. and Pearson, H. A.: Successful treatment of Pneumocystis carinii pneumonitis in a patient with congenital hypogammaglobulinemia. New Engl. J. Med. 272: 708-713 (1965).

52. Blattrer, R.J.: Pneumocystis carinii infection: Treatment with pentamidine isothionate. J. Pediat. 67: 332-335 (1965).

53. Patterson, J.H.; Lindsey, I. L.; Edwards, E.S. and Logan, Jr., W. D. : Pneumocystis carinii pneumonia and altered host resistance: Treatment of one patient with pentamidine isothionate. Pediatrics 38: 388-397 (1966).

54. Frenkel, J.K.; Good, J.T. and Shultz, J.A.: Latent Pneumocystis infection of rats, relapse, and chemotherapy. Lab. Invest. 15: 1559-1577 (1966).

55. Ricken, D.: Histologische Untersuchungen bei experimenteller Pneumocystis-Pneumonie. Virchows Arch.path. Anat. 331: 713-728 (1958).

56. WELLER, R.: Further studies of experimental cystic discase of the lungs in rats with special reference to interstitial pneumonia of the newborn. Z. Kinderheilk. 78: 166-176 (1956).

57. Sheldon, W.H.: Pulmonary Pneumocystis carinii infection. J. Pediat. 61: 780-791 (1962).

58. Pliess, G.: Interstitial plasma cell pneumonia of infants as a generalized disease. Frankfurt. Z. Path. 68: 565-595 (1957).

59. Michailov, G.: Morphological changes in lungs in Pneumocystis pneumonia. Zbl.allg. Path. path Anat. 96: 146-149 (1957).

60. Lyons, J.A.; Vinijchaikul, K. and Hennigar, G. R.: Pneumocystis carinii pneumonia unassociated with other disease. Clinical and pathological studies. Arch.intern. Med. 108: 929-936 (1961).

61. HAjDuk, A. : Certain aspects of the initial stages of interstitial pneumocystis pneumonias. Čs. Pediat. 15: 314-319 (1960).

62. Pavlica, F.: The first observation of congenital pneumocystic pneumonia in a fully developed stillborn child. Ann.paediat. (Basel) 198: 177-184 (1962).

63. Arean, V.: Neumocystosis pulmonar. Progr. Pat. Clín. 12: 1 (1965).

64. Burke, B.A.; Krovetz, L.J. and Good, R.A.: Occurrence of Pneumocystis carinii pneumonia in children with agammaglobulinemia. Pediatrics 28 : 196-205 (1961).

65. Muller-Eberhard, H.J. and Kunkel, H.G.: Ultracentrifugal characteristics and carbohydrate content of macromolecular gammaglobulins. Clin. chim. Acta 4: 252-258 (1959).

66. Gomori, G.: Silver impregnation of reticulum in paraffin section. Amer.J. Path. 13: 993 (1937).

67. Hamperl, H. : Demonstration of parasites in interstitial plasmocellular pneumonia. Klin. Wschr. 30: 820-822 (1952).

68. GARsche, R.: Clinical importance of roentgen diagnosis in interstitial pneumonia of premature infants. Fortschr. Röntgenstr. 75: 125-138 (1951).

69. BAAR, H.S. : Interstitial plasma cellular pneumonia due to Pneumocystis carinii. J.clin. Path. 8: 19-24 (1955).

70. Gagne, F. and Hould, F.: Interstitial plasmacellular (parasitic) pneumonia in infants; report of 3 cases. Canad.med. Ass. J. 74: 620-624 (1956).

71. Rowe, C.W.: Pneumocystis carinii pneumonia. Radiology 75: 257-261 (1960).

72. Rubin, E. and ZAK, F.G.: Pneumocystis carinii pneumonia in the adult. New Engl.J. Med. 262: 1315-1317 (1960).

73. LebedA, D.: Spontaneous fractures of the ribs "from fatigue" in infants. Čs. Pediat. 16: 667-670 (1961).

74. White, W.F.; Saxton, H. M. and Dawson, L. M.P.: Pneumocystis pneumonia. Report of 
three cases in adults and one in a child with a discussion of the radiological appearances and predisposing factors. Brit.med.J. 5263: 1327-1331 (1961).

75. Hennigar, G. R.; Vinijchaikul, K. ; Roque, A. L. and Lyons, H. A. : Pneumocystis carinii pneumonia in an adult. Report of a case. Amer.J.clin. Path. 35: 353-364 (1961).

76. Feinberg, S.B.; Lester, R.G. and Burke, B.A.: The roentgen findings in Pneumocystis carinii pncumonia. Radiology 76: 594-600 (1961).

77. Holland, P.D. and Ward, O.C.: Pneumocystis carinii pneumonia. Irish J.med. Sci. 438: 258-261 (1962).

78. Hendry, W.S. and Patrick, R.L.: Observations on thirteen cases of Pneumocystis carinii pneumonia. Amer. J. clin. Path. 38: 401-405 (1962).

79. Robillard, G.; Bertrand, R.; Gregoire, H. and BERDNikoff, G. : Plasma cell pneumonia in infants. Review of 51 cases. J. Canad. Ass. Radiol. 16: 161168 (1965).

80. Murray, J.F.; Haegelin, H.F.; Hewitt, W. L.; Latta, H.; McVickar, D. ; Rasmussen, A.F., Jr. and Rigler, L.G.: Opportunistic pulmonary infections. Ann.intern. Med. 65: 566-594 (1966).

81. Gruenwald, P. and Jacobi, M.: Mononuclear pneumonia in sudden death or rapidly fatal illness in infants. J. Pediat. 39: 650-662 (1951).

82. Russell, J.G.: Pneumocystis pneumonia associated with agammaglobulinemia. Arch. Dis. Childh. 34: 338-341 (1959).

83. Cahalane, S. F.: Pneumocystis carinii pneumonia. Report of a case and review of the litcrature. J. Irish med. Ass. 50: 133-136 (1962).

84. Lunseth, J. H.; Kirmse, T.W.; Prezyna, A.P. and Gerth, R. E.: Interstitial plasma cell pneumonia. J. Pediat. 46: 137-145 (1955).

85. Feinerman, B. and Harris, L. E.: Unusual interstitial pneumonitis; report of two cases occurring in children. Proc. Mayo Clin. 32: 637-640 (1957).

86. Wolman, M. and Goldberg, M.G.: The microcopical criteria of interstitial pneumonia. Arch. Path. 65: 272--278 (1958).

87. Rosen, H.S.; Castleman, B. and Liebow, A.A.: Pulmonary alveolar proteinosis. New Engl. J. Med. 258: 1123 (1958).

88. De SAnctis, P. N.: Pulmonary alveolar proteinosis. Boston med.Quart. 13: 19-25 (1962).

89. Rifkind, D.; Faris, T. D. and Hill, R. B.: Pneumocystis carinii pneumonia. Ann. intern. Med. 65 : 943 (1966).

90. Erchll, J.W.; Williams, L.P. and Meighan, P.P.: Pneumocystis carinii in hypopharyngeal material. New Engl. J. Med. 267: 926-927 (1962).

91. TAn-Vinh, L.; Cochard, A. M.; Vu-Trieu-Dong, and Solonuar, W.: Diagnostic in-vivo de la pneumonie a pneumocystis. Arch. franç. Pédiat. 20:773 (1963).

92. Fulginiti, V.A.: Case report. Personal communication.

93. Muller, H. and Vietor, G.: Clinical and epidemiological aspects of interstitial plasma cell pneumonia in young children. Z. Kinderheilk. 79: 40-48 (1957).

94. Stopka, E.; Wunderlich, C. and Garlson, S.: Morphological and cultural studies of Pneumocystis in sputum and lung material. Z. Kinderheilk. 79: 246-263 (1957).

95. Bachman, K. D. : Epidemiology and incubation of interstitial pneumonia. Z. Kinderheilk. 74: 133 (1954).

96. Anderson, C. D. and Barrie, H.J.: Fatal pneumocystis pneumonia in an adult. Report of a case. Amer.J.clin. Path. 34: 365-370 (1960).

97. Nicastri, A.D.; Hutter, R.V.P. and Collins, H.S. : Pneumocystis carinii pneumonia in an adult; emphasis on ante-mortem morphologic diagnosis. N.Y. State J. Med. 65: 2149-2154 (1965).

98. Bencroft, D. M. and Costello, J. M.: Pneumocystis carinii pneumonia in siblings: diagnosis by lung aspiration. N.Z.med.J. 64: 273-280 (1965).

99. Gaensler, E.A.; Molster, V.B. and Hamm, J.: Open-lung biopsy in diffuse pulmonary disease. New Engl.J. Med. 207: 1319 (1964).

100. Donohue, W.: Interstitial plasma cell pneumonia. Labor. Invest. 5: 97-105 (1956).

101. Lim, S. K. and Moon, C.J.: Studies on Pneumocystis carinii pneumonia: II. Epidemiological and clinical studies of 80 cases. Jonhap. Med. 6: 77 (1960).

102. Paltrzscir, D. von and Goetz, O.: Diaplacental transfer of antibodies against interstitial plasma cell pneumonia. Arch. Kinderheilk. 173: 27-31 (1965).

103. Tobler, W.: La prophylaxie de la pneumonie interstitielle, par l'irradiation non interrompue aux rayons ultra-violets des boxes. Ann. paediat. (Basel) 187: 284 (1956).

104. von HARnack, G.A.: Organizational problems in the prevention of interstitial pneumonia. Mschr. Kinderheilk. 108: 159-161 (1960).

105. WALTHER, T.: Interstitial plasma cell pneumonia; report of two cases. Acta Paediat. 39: 545-553 (1950).

106. Gormsen, H.: On interstitial plasma cell pneumonia in infants. Acta Paediat. Stockh. 39: 4-5, 291-314 (1950).

107. Deamer, W.C. and Zollinger, H. U.: Interstitial plasma cell pneumonia of premature and young infants. Pediatrics 12: 11-22 (1953). 
108. Sternberg, S.D. and Rosenthal, J.H.: Interstitial plasma cell pneumonia. J.Pediat. 46: 380 393 (1955).

109. Gerrard, J.W. and Moore, D.F.: Interstitial plasma cellular pneumonia due to pneumocystis carinii. Canad.med. Ass.J. 76: 299-302 (1957).

110. Eberling, E.W. and Cohen, F.: Pneumocystis carinii pneumonia; report of a case from Southwestern U.S. Pediatrics 21: 345-352 (1958).

111. Howard, R.M. and Sheldon, W.H.: Pneumocystis pneumonia; report of a case. J. Dis. Child. 95: 18-24 (1958).

112. Russell, H.T. and Nelson, B. M.: Pneumocystis pneumonitis in American infants. Amer.J.clin. Path. 26: 1334-1340 (1956).

113. Berlin-Heimendaht, S. von und Goetz, O. : Zur Epidemiologie, Therapie, und Prophylaxe der interstitiellen Säuglingspneumonie. Z. Kinderhcilk. 79: 689 (1957).

114. McNeal, J. E. and Yaeger, R.G.: Observations on a case of pneumocystis pneumonia. Arch. Path. 70: 397-406 (1960).

115. Stinson, J. C.; Lea, W.A., Jr.; Wood, H. L. and Cramm, C.J., Jr.: Cocxisting heart disease, Sclerema Neonatorum, and possible portozoan infection. J. Amer. med. Ass. 181: 899-901 (1962).

116. Dulitzky, M.E. and Repetti, L. P.: "Pneumocystis Carinii" pneumonitis. Plasma cell pneumonia in infants. La Semana Medica 122: 265270 (1963).

117. Huneycutr, H.C.: Pneumocystis carinii pneumonia. Case studies with electron microscope. Amer.J.clin. Path. 41: 411-418 (1964).

118. Cabrera, H.A. and Davis, G.H.D.: Epidemic meningitis of the newborn caused by Flavobacteria. Amer. J. Dis. Child. 101: 289 (1961).

119. Lim, S. K. and Moon, C.J.: Studies on Pneumocystis carinii pneumonia. I. Epidemiological and clinical studies of 80 cases. Jonhap. Med. 6: 69 (1960).

120. Watanabe, J. M.; Chinchinian, H.; Weitz, C. and MaIlvanie, S.K.: Pneumocystis carinii pncumonia in a family. J.amer. med. Ass. 193: 685-686 (1965).

121. Hyun, B.H.; Varga, C.F. and Thalheimer, L. J.: Pneumocystis carinii pneumonitis occurring in an adopted Korean infant. J.amer. med. Ass. 195: 784-786 (1966).

122. Zhukova, E.K.: A case of pneumoceptic pneumonia combined with generalized cytomegaly in a child. Arkh. Pat. 24: 68-71 (1962).

123. Drube, H.: The treatment of early infantile interstitial plasma cell pneumonia with moronaltacholiquin acrosols. Münch.med.Wschr. 101: 1414 1417 (1959).
124. Dvorak, J. and Jirovec, O.: Diagnosis and therapy of parasitic atypical pneumonia in infant caused by Pneumocystis carinii. Acta paediat. (Stockh.) 42: 232-245 (1953).

125. Eberle, H.: Öst.Z. Kinderheilk. 9: 421 (1954).

126. Fingerland, A. and Vortel, V.: Pneumocystis pneumonia. Schweiz.Z.allg. Path. 17: 201-220 (1954).

127. Koecher, P.H.: The problem of disposition to early infantile interstitial pneumonia. Mschr. Kinderheilk. 104: 322-325 (1956).

128. Kolaczek, B. et al.: Congenital tuberculosis and pneumocystic infection. Čs. Pediat. 20: 629-633 (1965).

129. Offenhauer, R.: Epidemiological aspects and symptomatology of interstitial plasma cell pneumonia. Z. Kinderheilk. 90: 251-262 (1964).

130. Schmoger, R.: 502 Fälle interstitieller Pneumonic eigener Beobachtung. Z. Kinderheilk. 79: 522 (1957).

131. Weisse, K. and Wedler, E.: Occurrence of the so-called Pneumocystis carinii. Klin. Wschr. 32: $11-12,270-271$ (1954).

132. Wilson, J. F.; Crass, G. and Garza, B. L.: Pneumocystis carinii pneumonia. Report of a case and review of the recent literature. Pediatrics 25: 468476 (1960).

133. Toldyova, V.: Apropos of interstitial pneumocystic pneumonia in pediatric institutions. Bratisl. lek. Listy 44: 230-236 (1964).

134. Bird, T. and Thomson, J.: Pneumocystis carinii pneumonia. Lancet 272: 59-64 (1957).

135. Chagas, C. : Nova tripanozomiaza humana. Inst. Oswaldo Cruz, Rio 3: 219 (1911).

136. Robinson, J.J.: Two cases of pneumocystis. Observation in 203 adult autopsies. Arch. Path. 71: 156-159 (1961).

137. Kaftori, J. K. ; Bassan, H.; Gellei, B. and GrifFEL, B.: Pneumocystis carinii pneumonia in the adult. Report of a primary case. Arch. intern. Med. 109: 438-446 (1962).

138. Trmmel, H. : Electronoptic studies on cytomegalia nuclear inclusions. Frankfurt.Z.Path. 73: 514519 (1964).

139. Symmers, W.S.: Generalized cytomegalic inclusion-body disease associated with Pneumocystis pneumonia in adults. J.clin. Path. 13: 1-21 (1960).

140. Rifkind, D.; Starzl, T.E.; Marchioro, T.L.: Waddell, W.R.; Rowlands, J.T. and Hill, R. B.: Transplantation pneumonia. J. amer. med. Ass. 189: 808-812 (1964).

141. Nakamura, R.M.: Coexistent cytomegalic inclusion disease and pneumocystis carinii infection in adults. Acta path. jap. 14: 45-59 (1964). 
142. Kramer, R.I.; Girone, V.C. and Moore, H.: Interstitial pneumonia due to Pneumocystis carinii, cytomegalic inclusion disease and hypogammaglobulinemia occurring simultaneously in an infant. Pediatrics 29: 816-827 (1962).

143. Hamperl, H.: Pneumocystis infection and cytomegaly of the lungs in the newborn and adult. Amer. J. Path. 32: 1-13 (1956).

144. Williams, G.; Stretton, T.B. and Leonard, J. C. : Cytomegalic inclusion disease and pneumocystis carinii infection in an adult. Lancet $i i$ : 951955 (1960).

145. WEISSE, K.: Generalized cytomegaly and localized pneumocystosis in a case of infantile interstitial plasma cell pneumonia. Z. Kinderheilk. 76: 27-32 (1955).

146. Winslow, D.J. and Hathaway, B. M. : Pulmonary pncumocystosis and cryptococcosis. Amer.J. clin. Path. 31: 337-342 (1959).

147. Astor, K. and Schreier, K.: On an epidemic of interstitial and suppurative pneumonia and of mixed forms. Ann. peadiat. (Basel) 194: 1-10 (1960).

148. Dauzier, G.; Willis, T. and Barnett, R.N.: Pneumocystis carinii pneumonia in an infant. Amer.J.clin. Path. 26: 787-793 (1956).

149. MaKay, E. and Richardson, J.: Pneumocystis carinii pneumonia associated with hypogammaglobulinemia. Lancet ii: 713 -715 (1959).

150. Cohen, W.N. and McAlister, W.H.: Pneumocystis carinii pneumonia. Report of 4 cases. Amer. J. Roentgenol. 89: 1032-1037 (1963).

151. Bouton, J.; Mainwaring, D. and Smitiells, R.W.: BCG dissemination in congenital hypogammaglobulinemia. Brit.med.J. $i$ : 1512-1515 (1963).

152. Collier, F.C.: Pneumocystis carinii pneumonitis. Missouri Med. 61: 772-774 (1964).

153. Allibone, E. C.; Goldie, W. and Marmion, B.P.: Pncumocystis carinii pneumonia and progressive vaccine in siblings. Arch. Dis. Childh. 39: 26-34 (1964).

154. Dorson, T. and Kapcar, Jr., A.J.: Pneumocystis carinii pneumonia with hypogammaglobulinemia. W.Va.med.J. 61: 31-34 (1965).

155. Schaller, J.; Ching, Y.; Williams, C.P.S.; Davis, S.D.; LagunofF, D. and Wedgwood, R.J.: Hypergammaglobulinemia, antibody deficiency, autoimmune haemolytic anemia, and nephritis in an infant with a familiar lymphopenic immune defect. Lancet ii: 00-000 (1966).

156. Robins, J. B.: Unpublished case.

157. Roos, B. and Keller, H.: Pneumocystis pncumonia after corticoid therapy. Path. et Microbiol. (Basel) 23: 277-283 (1960).
158. Muller, G.: Interstitial plasma cell pneumonia after corticosteroid therapy. Frankfurt.Z. Path. 70: 657-675 (1960).

159. Aherne, W.: A case of osteopetrosis (Albers Schonberg) with intercurrent pneumocystis pneumonitis. Arch. Dis. Childh. 35: 495-502 (1960).

160. Kosser, A. : Interstitial plasma cell pneumonia in older children following prolonged corticosteroid treatment. Report on 13 cases. Dtsch. med.Wschr. 87: 1133-1139 (1962).

161. Goetz, O. and Ohrt, B.: Long-term cortisone therapy and interstitial pneumonia. Mschr. Kinderheilk. 112: 163-164 (1964).

162. Gilbert, C.F.; Fordham, C.C. and Benson, W.R.: Death resulting from Pneumocystis pneumonia in an adult. Arch. intern. Med. 112: 158163 (1963).

163. Mirejovski, P.: Pneumocystic pneumonia with rupture of the right cardiac appendage after corticoid administration. Cs. Pediat. 19: 731-735 (1964).

164. Marki, H.H. von und Wick, A.: Transitorische Hypogammaglobulinämie nach Goldtherapie. Schweiz. med. Wschr. 94: 131-133 (1964).

165. Dyszy-Laube, B.: Pneumocystis carinii in children with hematological diseases. Pediat. pol. 39: 1193-1197 (1964).

166. da Silva, G.; Gomes, M.C. and Santos, R. F.: Pneumocystis pneumonia in the adult. Report of case associated with corticosteroid therapy for rheumatoid arthritis. Rev. Inst. Med. trop. S.Paulo 7: 31-38 (1965).

167. Irving, W.R., Jr.; Mare, A. and Mtale, J.B.: Unusual infection in lymphoma and leukemia. Sth. med.J. 58: 891-895 (1965).

168. Bosman, C.: Hypervitaminosis D and pneumocystis pneumonia in an infant. Helv. paediat. Acta 20: 300-309 (1965).

169. Esterly, J.A. and Warner, N. E. : Pneumocystis carinii pneumonia. Twelve cases in patients with neoplastic lymphoreticular disease. Arch. Path. 80: 433-441 (1965).

170. Callerame, M. L. and Nader, M. : Pneumocystis carinii pneumonia in two adults with multiple myeloma. Amer. J. clin. Path. 45: 258-263 (1966).

171. Data kindly made available by Dr. Eugene SMITH, Closter, N.J.

172. Data kindly made available by Dr. EMANuEL KAUDER, University of Cincinnati.

173. Bernier, G.M. and Putnam, F.W.: Myeloma proteins and macroglobulins: Hallmarks of disease and models of antibodies; in Progress in Hematology, ed. Carl V. Moore and Elmer B. Brown, vol.4, p. 160 (Grune and Stratton, New York 1964). 
174. Ultmann, J.E.; Fish, W.; Osserman, E. and Gellhorn, A.: The clinical implications of hypogammaglobulinemia in patients with chronic lymphocytic leukemia and lymphocystic lymphosarcoma. Ann. intern. Med. 51: 501-516 (1959).

175. Goetz, O. and Rentsch, L.: Weitere Untersuchungen zur cxperimentellen Rattenpneumocystose. Z. Kinderheilk. 79: 578 (1957).

176. Kerpel-Fronius, F.; Varga, F. and Bata, G.: Blood gas and metabolic studies in plasma cell pneumonia and in newborn prematures with respiratory distress. Arch. Dis. Childh. 39: 473-480 (1964).

177. Droese, W.: Acid-base equilibrium of premature infants; special characteristics in plasmacellular pneumonia. Helv. paediat. Acta 10: 97-103 (1955).

178. VArga, F.: Hypoxia and metabolic disturbances in plasma cell interstitial pneumonia of premature and undernourished infants. Čs. Pediat. 20: 317 319 (1965).

179. Goetz, O. und Rentsch, L.: Prüfung der Wirkung von UV-Licht und medikamenten auf Pneumocystis carinii im Ticrversuch. Z. Kinderheilk. 79: 305 (1957).

180. Maneke, M.: Therapy of interstitial plasma cell pneumonia in young and premature infants. Mschr. Kinderhcilk. 102: 485-487 (1954).

181. LAursen, H.: Interstitial plasma cell pneumonia in premature infants. Nord. Med. 54: 1285-1288 (1955).
182. Kaloud, H.: Treatment of interstitial plasma cell pneumonia with hydrated ergot alkaloids. Wien. med. Wschr. 108: 299-301 (1958).

183. Kalous, H.: On the treatment of interstitial plasma cell pneumonia with hydrogenated ergot alka!oids. Mschr. Kinderheilk. 108: 161-164 (1960).

184. Joppich, G.: Unsere Erfahrungen mit der Chloromycetin-Behandlung bei der interstitiellen Pneumonic der Frühgeborenen. Ann. paediat. (Basel) 180: 264 (1953).

185. Goodman, L.S. and Gilman, A.: The pharmacological basis of therapeutics; 3rd ed., p. 1101 (Macmillan, London/Toronto 1965).

186. Data kindly made available to us by Dr.P.CAtalbano, San Diego, Calif., and Dr. I. Liebow, New Haven, Conn.

187. Consultation and help from Dr. Vincent Fulginitı, Dr. Eugene Smith, Dr. Emanuel Kauder, Dr. Patricia Montalbano, Dr. Ralph Wedgwood, and Dr. Alvin RoBins are gratefully acknowledged.

188. The clinical use and evaluation of the drug, pentamidine isothionate, was facilitated under the direction of Dr. Francis Kelsey.

189. The author is recipient of N.I.H. Career Development Award No.6 K3-HD-22 856-0141. This investigation was partially supported by a N.I.H. Research Grant No.AI-HD-08768-01 A.I.A. and No. NIH-DH-06786-02. 